
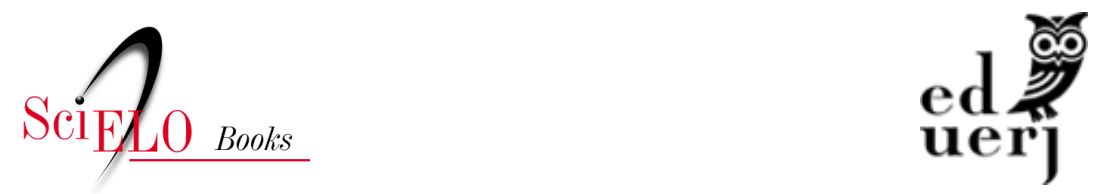

\title{
Capítulo IV - Experiências conectadas: relações e mediações docentes entre sociedades
}

Angélica Borges

\section{SciELO Books / SciELO Livros / SciELO Libros}

BORGES, A. Experiências conectadas: relações e mediações docentes entre sociedades. In: A urdidura do magistério primário na Corte Imperial: um professor na trama de relações e agências [online]. Rio de Janeiro: EDUERJ, 2021, pp. 261-319. ISBN: 978-65-87949-20-8.

https://doi.org/10.7476/9786587949208.0006.

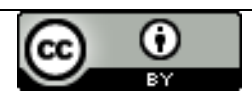

All the contents of this work, except where otherwise noted, is licensed under a Creative Commons Attribution 4.0 International license.

Todo o conteúdo deste trabalho, exceto quando houver ressalva, é publicado sob a licença Creative Commons Atribição 4.0.

Todo el contenido de esta obra, excepto donde se indique lo contrario, está bajo licencia de la licencia Creative Commons Reconocimento 4.0. 


\section{Capítulo IV \\ Experiências conectadas: relaçóes e mediaçôes docentes entre sociedades}

As nações mais adiantadas aprendem todos os

dias umas com as outras...

Professor Costa e Cunha (1873)

A circulação de objetos culturais, modelos pedagógicos e pessoas entre mundos tem sido uma problemática que vem recebendo enfoque significativo na História da Educação brasileira. Vidal (2006) considera que a categoria "circulação" torna-se fértil em razão de poder deslocar "a ênfase de um ponto original de partida (ou de difusão) para vários centros difusores”, como também por considerar "as mestiçagens operadas no movimento mesmo de passagem das ideias, pessoas e objetos pelas sociedades e culturas” (p. 245, grifo da autora). A proposta deste capítulo, nesse sentido, tem como objetivo realizar uma reflexão a partir da perspectiva de "histórias conectadas", buscando apreender a interlocução dos professores públicos primários da Corte com saberes, sujeitos ou experiências advindos de outros lugares, mais especificamente, em conexão com a França, por meio do professor Candido Matheus de Faria Pardal. Para tanto, apresento um abordagem da circulação das ideias francesas entre os professores, seguida de uma análise acerca da criação e do funcionamento das escolas municipais dirigidas por Pardal, nas quais implementou um programa baseado no sistema de Jean-Jacques Rapet, a fim de compreender as condições de aparecimento dos pensamentos desse inspetor francês no círculo docente, bem como a forma como foram apropriados por Pardal.

Os conceitos de "história comparada" e de "história conectada" podem emergir como possibilidade fértil de análise das trajetórias docentes. No debate em torno desses conceitos importa destacar a reflexão de Detienne (2004) de 
“construir comparáveis" a partir de um conjunto de precauções metodológicas, em que não se torna necessário atribuir semelhanças para fazer comparação, mas sim buscar um território em comum para observar a adesão dos sujeitos a uma geografia. Vale também atentar para Gruzinski (2001 e 2003) quando opera com o conceito de "connected histories" assinalando que o "historiador tem de converter-se em uma espécie de eletricista encarregado de restabelecer as conexões internacionais e intercontinentais que as historiografias nacionais desligaram ou esconderam" (2001, p. 176).

No caso da Corte, dois espaços, entre outros, destacam-se em relação aos registros de troca e de circulação de ideias, modelos e referências a materiais pedagógicos entre os professores: a imprensa pedagógica e as Conferências Pedagógicas, organizadas pelo governo imperial nas décadas de 1870 e 1880.

Teixeira (2016), ao tratar da imprensa pedagógica no período de 1870 a 1919 , entende os jornais e as revistas como agentes construtores da escola, sendo, portanto, lugares privilegiados para circulação de ideias. A autora assinala que a imprensa pedagógica se constituiu no interior de um campo de lutas, usada por professores, alunos e autoridades governamentais para intervir no funcionamento da escola e nas questões educacionais. Por meio dela "faziam circular informações, expunham e debatiam ideias e se esforçavam para persuadir seus pares" (2016, p. 293).

Nos documentos existentes acerca das Conferências, podemos ver os próprios professores públicos primários fazendo um exercício de comparação ao expor seus trabalhos, previamente elaborados com base numa pauta de discussão estabelecida pelo governo. O exercício remete ao estado da educação em diversos países, como Portugal, Estados Unidos, Suíça, França, entre outros. Professores comparavam práticas escolares, formas de organização do ensino, usos de materiais e livros. Colocavam as ideias em circulação abordando tanto a produção estrangeira quanto a nacional e, em vários casos, ressaltando a qualidade da produção dos próprios colegas professores da Corte: uma produção nacional, mas conectada com os países estrangeiros.

Nesses documentos encontra-se uma espécie de parecer em torno dos trabalhos apresentados durante a primeira edição das Conferências Pedagógicas (1873). O professor do Imperial Colégio de Pedro II e membro do Conselho Diretor da Instrução, Philippe da Motta Azevedo Corrêa, foi encarregado da tarefa de elaborar os "pareceres". Preocupado com a necessidade do professor "gravar na alma infantil o amor do bem e a prática da virtude", sugere que o 
governo mande traduzir e distribuir gratuitamente pelas escolas alguns tratados de pedagogia. Menciona, como exemplo, os autores Rendu, Barrau, Braun, Dunn, Zweiler, Fröebel, Rapet, Daligault, Naville e Théry - a maior parte deles citada pelos próprios professores nas conferências, conforme sinalizam as atas do evento. Também apresenta uma pauta de nove medidas que deveriam ser tomadas pelo governo imperial, entre elas, a criação de uma escola normal. Porém, alerta para a necessidade de se enviar antes uma comissão para estudar a organização das melhores escolas normais na Europa e nos Estados Unidos e para ir à Exposição Internacional de Viena com o objetivo de

[... estudar todos os progressos na arte de ensino e na ciência pedagógica, apresentando relatório circunstanciado sobre os assuntos compreendidos no grupo 26 da classificação da dita Exposição; e que represente o Brasil nas conferências pedagógicas as quais todos os países enviam uma comissão dos seus professores (Relatório dos trabalhos que foram lidos e do debate oral que teve lugar nas conferências pedagógicas, 1873, p. 29-30. In: Relatório da IGIPSC 1872-2A).

Anos depois, o próprio professor Philippe da Motta foi encarregado, por Decreto de 29 de fevereiro de 1876 , de estudar a seção de instrução pública da Exposição da Filadélfia, bem como percorrer os Estados Unidos, Alemanha, Holanda, Suíça, França, Suécia, Itália e Portugal para conhecer uma série de aspectos relativos ao ensino, listados nas instruções que recebeu para a viagem (Relatório da IGIPSC do ano de 1877, p. 5-6). Na Exposição da Filadélfia, segundo Ferreira Vianna, uma escola municipal dirigida por Pardal teria ganho um prêmio (O Cruzeiro, 15 nov. 1878).

Os professores faziam diferentes usos das ideias advindas do estrangeiro em solo carioca, mas também almejavam a apropriação das mesmas a partir de uma imersão cultural in loco, ao demonstrarem interesse em viajar para o exterior. Segundo Schueler (2007a), as viagens pedagógicas funcionavam como uma formação em serviço, uma experiência de conhecimento, aprendizagem e de produção de um discurso de mediação cultural. Esse era o caso, por exemplo, do professor primário Olympio Catão Viriato Montez, na época regente da escola pública da freguesia de Guaratiba, que, em um livro de sua autoria, "Modo de reger uma escola de Instrução Pública” (1871), relatou seu desejo de viajar para Europa a fim de conhecer escolas (AGCRJ, códice 10.4.2, f. 70). Embora não constasse que Montez tivesse conseguido realizar seu desejo, alguns professores 
primários iriam fazer viagens pedagógicas, como no caso de Luiz Augusto dos Reis, conforme o estudo de Garcia (2011) e o de Manoel Frazão (Schueler, 2007).

\section{As ideias francesas em pauta nas Conferências e na imprensa}

Nas atas das conferências, um dos aspectos que se destaca nas menções às ideias estrangeiras é o significativo contato dos professores da Corte com diversas obras e materiais franceses. Bastos (2000), em estudo sobre as ideias pedagógicas de Ferdinand Buisson no Brasil, afirma que o século XIX brasileiro poderia ser considerado um século de "francofonia por excelência" em razão da cultura ter "absorvido" quase tudo o que se produziu na França. A autora, contudo, restringe, de certa forma, a sua apropriação à "elite intelectual” brasileira. Portanto, também cabe ressaltar que tanto ideias vindas de outros países, como dos Estados Unidos, faziam-se bastante presentes quanto eram apropriadas de variadas formas por outros grupos da sociedade, como os professores públicos primários.

Em um momento em que a formação docente se dava de diferentes maneiras, de que modo eles tinham acesso a essa variedade de ideias e materiais? As explanações dos professores primários durante as conferências e também na imprensa confirmam que o acesso ocorria de múltiplas formas. Diferentes espaços de sociabilidade que contavam com bibliotecas, periódicos nacionais e estrangeiros em seus acervos (SAIN, Sociedade Propagadora das Belas Artes, Colégio de Pedro II), bem como reuniões de estudo como, por exemplo, na Academia Pedagógica e no Atheneu Pedagógico (Diário do Rio de Janeiro, 03 jun. 1877), constituem ambientes nos quais professores poderiam acessar e compartilhar ideias pedagógicas.

Mas as bibliotecas não eram restritas a tais ambientes. Vários professores públicos primários tiveram a iniciativa de montar bibliotecas nas escolas em que atuavam, como os professores Costa e Cunha e Guilhermina de Azambuja Neves, noticiada na Gazeta de Notícias (22 ago. 1877). Ambos os professores mobilizavam pessoas em busca de donativos para o empreendimento. No caso de Guilhermina, a nota anunciava sua pretensão de "organizar uma biblioteca de trabalhos didáticos de instrução primária”, para a qual esperava "contar com seus colegas e todas as pessoas que a queiram coadjuvar” (Gazeta de Notícias, 22 ago. 1877).

Um artigo publicado pelo professor Augusto Cony, no periódico $A$ Instrucção Pública (04 maio 1873), sobre as Conferências Pedagógicas, assinala a atividade de estudo e de reflexão em torno da própria prática: "Os mentores encontrei-os nos 
livros que consultei; as inspirações bebi-as na mesa do estudo e do trabalho, onde sempre me achei a sós com as reflexões que me sugeria a própria prática do ensino" (p. 137). O depoimento nos remete a dois aspectos importantes. O primeiro é a confirmação de que o professor acessava obras pedagógicas, entre elas as estrangeiras, como pode ser notado nas suas exposições durante as conferências. $\mathrm{O}$ segundo, o de que não era uma leitura passiva, mas em diálogo com a sua própria experiência, demonstrando o exercício de uma "apropriação criativa" (Vidal, 2005 e Certeau, 1994) ou até mesmo de uma atividade intelectual mais elaborada.

No conjunto de artigos publicados em torno da polêmica da reprovação da gramática de Vergueiro e Pertence pela comissão formada por Pardal e mais três professores, podemos observar também o conhecimento de obras francesas e uma postura crítica em relação a elas.

Aí ver-se-á que a gramática dos Srs. Vergueiro e Pertence é uma compilação sem critério de trechos de diversas obras, às vezes em contradição uns com os outros; que nela leem-se regras textualmente extraídas de Noël e Chapsal que não têm aplicação à língua portuguesa; que há regras tão inconsideradamente apresentadas, que são destruídas pelos próprios exemplos; que há em certos pontos tal anfibologia que ninguém os pode entender; que finalmente em outras quer a linguagem, quer a doutrina estão fora de alcance dos meninos. (Diário do Rio de Janeiro, 11 out. 1862).

A quantidade de obras mencionadas e de trechos citados, até mesmo na língua original, trazidas para sustentar o debate, indica que os professores tinham acesso a livros considerados de referência. O caso dos gramáticos franceses François-Joseph-Michel Noël e Charles-Pierre Chapsal, que os professores identificaram na obra de Vergueiro e Pertence, é um exemplo. Os professores tanto conheciam a obra desses pensadores como trouxeram trechos do original em francês para criticar a forma como eles foram apropriados por Vergueiro e Pertence, como na definição de "adjetivos determinativos" e "adjetivos indefinidos":

E esta definição, também extraída de Noël e Chapsal, é pior do que a destes autores, que assim se exprimem: «Les adjectifs indefinis determinent la signification du substantif en y ajoutant pour la plus part une idée de generalité ». Os Srs. Vergueiro e Pertence traduzindo quase literalmente este trecho, infelizmente truncam-no suprimindo - pour la plus part -; e por isso a uma definição que já 
não era boa tornaram péssima, convertendo-a em completa falsidade (Díário do Rio de Janeiro, 13 out. 1862, grifos no original).

Ao longo do texto, os professores fizeram vários contrapontos entre as afirmações de Vergueiro e Pertence e as ideias dos gramáticos Noël e Chapsal, querendo, sobretudo, ressaltar que algumas regras só faziam sentido para língua francesa e não para a portuguesa, argumento que visava igualmente justificar o motivo da preferência pela gramática do professor Polycarpo Dias da Cruz, já mencionada.

Nas Conferências de 1873, diversos exemplos foram mencionados em defesa do uso de ideias, métodos e materiais franceses. Phillipe de Barros era favorável ao uso do aparelho inventado por Mr. Level, professor do Baixo-Reno, na França, para o ensino do sistema métrico. O método Sarrazin foi defendido pelo professor Gustavo José Alberto e, segundo ele, era adotado na Escola Normal de Paris (França) e também na Escola Normal da Bahia (Brasil), na qual se formou. Olympio Montez observou que: "já em 1838 em Paris se procurava ensinar a leitura conjuntamente com a caligrafia. Assim diz um membro da Universidade em seu Manual das escolas primárias" (Trabalho do professor Olympio Catão Viriato Montez, p. 7, Relatório... 1872-2A, A-B12-7). A ponderação demonstrava o conhecimento do professor sobre o assunto e igualmente funcionava como um alerta às autoridades para o fato de que a questão já parecia superada em outros países, que tinham adotado o "novo" formato havia bastante tempo.

Phillippe da Motta também elaborou comentário em torno de algumas práticas e objetos usados nas escolas francesas, provavelmente, baseado no conjunto de trabalhos apresentados pelos professores.

Nas escolas da França não se passa para o cálculo escrito sem que o menino esteja habilitado a fazer as 4 operações fundamentais verbal e mentalmente, assim como a calcular praticamente pelo sistema métrico; para um e outro fim há em cada escola aparelhos apropriados como o boulier-compteur, o aparelho Level, os quadros Boniface, etc. além de uma série de modelos e padrões dos pesos e medidas do novo sistema; o estudo é feito sobre problemas com relação aos usos da vida e de que existem coleções apropriadas em diversos tratados especiais, particularmente na pequena aritmética de Guilmin, na coleção de Salgey, nos pequenos tratados de Dumouchel. Para esse fim existe também o engenhoso método usado nas salas de asilo e publicado por sua autora Mme. Pape Carpantier no seu curso de educação 
e de instrução primária; citarei também o método de Jorge Ritte e o engenhosíssimo método de João Macé, o mais apropriado possível aos meninos, ainda os de mais tenra idade, e a que ele deu o nome de Aritmética do Vovô (Arithmetique du grand papa). E por um processo análogo a este último método que nos Estados Unidos se ensina a aritmética elementar e o sistema métrico (Relatório..., p. 26 / 1872-2A, A-B7-26, grifos do autor).

Em que pese as várias referências à França, havia igualmente um posicionamento crítico em relação ao seu modelo pedagógico, conforme podemos observar na imprensa. O professor primário Antonio Estevão da Costa e Cunha assinalou, nesse sentido, que

Já que tocamos neste ponto permita-nos S.S. que lhe digamos que não é a França mais própria para dela recebermos inspirações em matéria de instrução, pois ela mesma para consertar e remendar a sua vai buscá-las na Inglaterra, nos Estados-Unidos e até na Prússia sua mortal inimiga (A Instrucção Pública, 14 jul. 1872).

No entanto, o número de referências aos franceses é considerável no próprio jornal A Instrucção Pública, de onde foi extraída a fala do professor. A folha pedagógica apresenta desde divulgação de decisões oficiais tomadas pelo governo francês no campo da educação até comentários de livros publicados recentemente na França, passando por dados estatísticos, discussão em torno do ensino obrigatório, o ensino de filosofia, a aprendizagem agrícola, a questão da higiene, a menção a pensadores da educação como Charbonneau, Théry, Rendu, Daligault, Dumouchel, Carpantier, Macé, Hippeau, entre vários outros assuntos.

A publicação de tradução de obras ou de trechos também fazia parte das colunas do jornal, como no caso do Conde Roselly de Lorgues, um dos fundadores do Journal des Instituteurs Primaires, em 1833 (D'Hauterive, 1963). O trecho publicado chamava-se "O mestre-escola", extraído da obra "Le livre des communes, ou Régénération de la France par le presbytère, l'école et la mairie”. A tradução imprensa na folha era de uma edição portuguesa, sinalizando que as ideias francesas poderiam chegar ao Brasil via outros países, principalmente, por meio de Portugal.

Entre os autores referenciados, está o inspetor francês Jean-Jacques Rapet, que aparece em 16 edições de $A$ Instrução Pública. Contribui para esta estatística o professor Candido Matheus de Faria Pardal, que obteve destaque no periódico 
em 1872 e 1873, ao apresentar seu programa baseado no sistema de Rapet. Tal destaque emerge em um momento em que os relatórios oficiais afirmavam que a maior parte das escolas públicas primárias do Rio de Janeiro não tinha programa, nem tabela de distribuição do tempo ou não seguia o programa existente. Outra problemática era a dificuldade em classificar e dividir os alunos em classes, já que, nesse período, uma escola pública primária na Corte tinha apenas um professor. Outro fator que favorece o destaque obtido por Pardal é o uso de um conhecimento pedagógico advindo do "mundo civilizado", o que serviria para legitimar e adornar a obra realizada, tendo em vista que nesse mesmo ano outros professores também apresentaram programas que elaboraram para uso nas escolas em que atuavam.

Compreender como se deu a presença das ideias de Rapet e de outros franceses na trajetória do professor Pardal, nos debates pedagógicos da Corte e nas escolas públicas da cidade pode tornar possível esmiuçar e compreender também importantes aspectos tanto das relações travadas entre os professores, governo e sujeitos escolares quanto da constituição do ofício de professor e do próprio processo de escolarização.

As apropriações que Pardal, um professor conhecido e respeitado na Corte, fez das ideias de Rapet e a considerável divulgação desse fato na imprensa pedagógica também nos colocam outras questões como: quais os seus efeitos no funcionamento das escolas municipais criadas (e construídas) na década de 1870 e no debate entre os professores da Corte sobre organização do ensino nas escolas públicas? As ideias de Rapet também teriam contribuído na elaboração do livro de gramática escrito juntamente com José Ortiz e na larga adoção do mesmo nas escolas da Corte, assim como em outras províncias do país?

Embora em posição distinta e sem a mesma frequência, as questões pedagógicas brasileiras também estavam em pauta nos periódicos pedagógicos na França. O Manuel Generale de l'Instruction Primaire traz algumas menções sobre o Brasil, como o estado da instrução no país e a introdução das Caixas econômicas escolares. Também cabe lembrar que o Dicionário Buisson faz menção às "trocas internacionais". Buisson assinala que "a ideia de uma troca de documentos, de publicações administrativas ou científicas, de livros raros, obras ou reprodução de obras de arte, etc., entre os governos, as sociedades sábias, as bibliotecas de 
diversos países, é já antiga” (1888, v.1, p. 752, tradução nossa). ${ }^{1}$ O Dicionário Buisson registra que a França instalou um serviço voltado para essa atividade no interior do Ministério da Instrução Pública e que

A França mantém hoje relações de trocas com a Bélgica, Suíça, Áustria-Hungria, Rússia, Portugal, Estados Unidos, Itália, China, Japão, Países Baixos, Brasil, etc. O movimento de volumes trocados em 1879 entre a França e seus correspondentes foi de 40.000 (1888, v. 1, p. 752, tradução nossa). ${ }^{2}$

Nesse sentido, Bastos (2002) também destaca a atuação de Célestin Hippeau, que pretendia tornar conhecida na França o funcionamento da instrução pública de outros países. A autora assinala o exercício feito por Hippeau e Ferdinand Buisson de realizarem uma espécie de educação comparada, cujas obras fariam parte das leituras de uma chamada "elite ilustrada" brasileira. No entanto, como pudemos observar pelas exposições feitas nas Conferências Pedagógicas, tais leituras também circulavam entre os docentes públicos primários. Cabe assinalar que, de acordo com Bastos (2002), uma das obras de Hippeau, L'instruction publique aux États-Unis, foi traduzida por ordem do governo imperial e publicada no Diário Oficial do Império do Brasil, em 1871. Esse procedimento poderia ter facilitado o acesso à obra por um maior número de pessoas.

\section{"Dar ao magistério público uma consideração": a direção das escolas municipais}

A Escola Municipal de São Sebastião, inaugurada em 4 de agosto de 1872 (Diário do Rio de Janeiro, 05 ago. 1872), e a de São José, em 7 de setembro de 1874 (A Instrução Pública, 13 set. 1874), eram as escolas dirigidas por Pardal que teriam recebido um prêmio na Exposição da Filadélfia. Ambas são geralmente mencionadas pela historiografia da educação como sendo parte do conjunto de escolas denominadas “do Imperador" em razão de D. Pedro II ter preterido a

${ }^{1}$ No original: "L'idée d'un échange de documents, de publications administratives ou scientifiques; de livres rares, ou d'objets de reproductions d'objets d'art, etc., entre les gouvernements, les sociétés savantes, les bibliothèques des divers pays, est déjà ancienne".

2 No original: "La France entretient aujourd'hui des relations d'échanges avec la Belgique, la Suisse, l'Autriche-Hongrie, la Russie, le Portugal, les États-Unis, l'Italie, la Chine, le Japon, les Pays-Bas, le Brésil, etc. Le mouvement des volumes échangés en 1879 entre la France et ses correspondants a été de 40.000". 
estátua, que seria feita em sua homenagem, em favor de usar os recursos para abrir escolas. No entanto, as fontes também mostram várias despesas no orçamento da Câmara Municipal com a construção dos prédios, como por exemplo, o Decreto n. ${ }^{\circ} 4662$ de 31 de dezembro de 1870 que orça as receitas e fixas as despesas da Câmara para o ano de 1871, o que assinala que os prédios foram erguidos com dinheiro arrecadado de mais de uma fonte, inserindo-se também as listas de subscrição de donativos.

A cerimônia de inauguração da Escola Municipal de São Sebastião contou com a presença de várias autoridades, como o presidente da Câmara Municipal, Antonio Ferreira Vianna - que também passara a ocupar o posto de inspetor das escolas municipais -, o secretário da Associação Municipal Protetora da Instrução da Infância Desvalida, Costa Ferraz e o Imperador. O Diário do Rio de Janeiro registrou que o prédio foi aberto para visitação pública e "a festa teve um caráter popular".

Figura 32 - Escola Municipal de São Sebastião

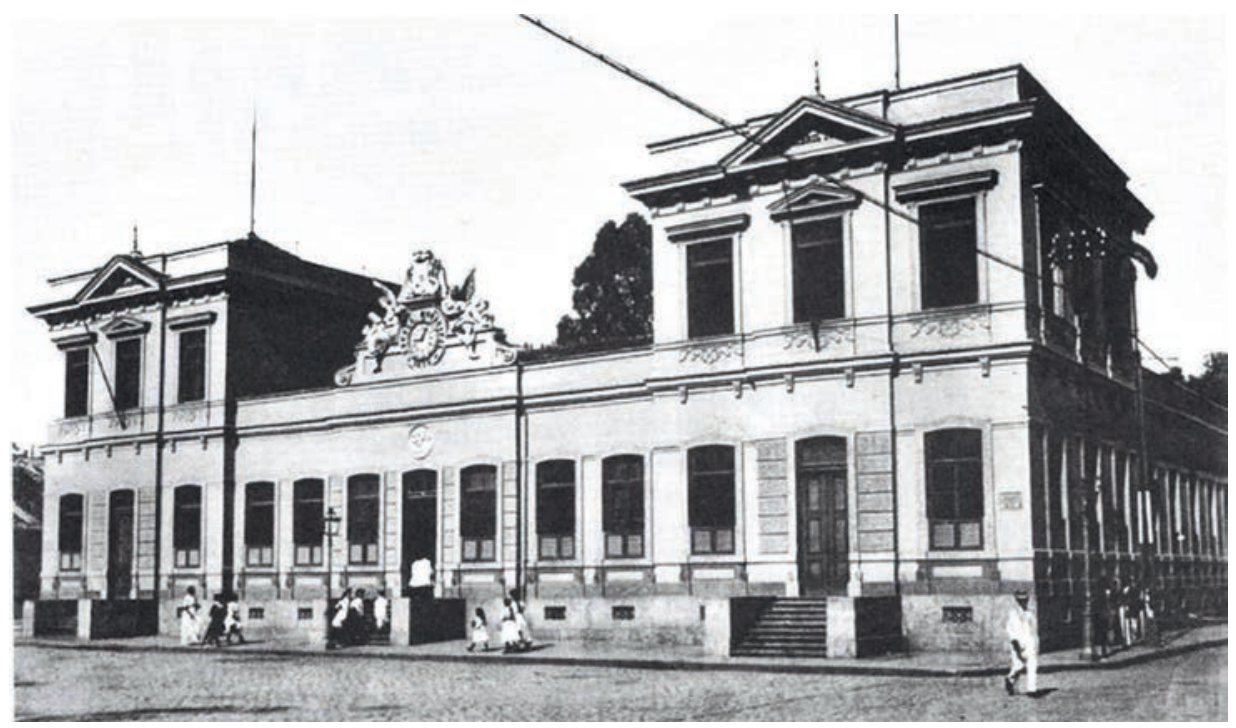

Fonte: Schueler e Gondra (2008).

A escola teria dois cursos abertos. O diurno, para as crianças de ambos os sexos (com entradas separadas, como é possível observar pela foto), e o noturno, para adultos. Outra atividade era a realização de conferências "por cidadãos habilitados". A primeira estava marcada para o dia 12 de setembro e seria proferida 
pelo próprio Antonio Ferreira Vianna no salão da biblioteca da escola que faria: “a primeira preleção de educação moral, à qual Sua majestade o Imperador se dignou prometer de assistir" (Diário do Rio de Janeiro, 05 ago. 1872).

"O edifício está acabado: mas quanto falta para se realizar a escola?", pergunta Ferreira Vianna em seu discurso de inauguração. Assinala que "quem inicia tão difícil serviço deve ter longa resignação para suportar as desconsolações da inexperiência”. O diretor nomeado por Ferreira Vianna, Candido Matheus de Faria Pardal, parecia se enquadrar no quesito mencionado por ele:

O ilustrado e provecto professor Candido Matheus de Faria Pardal tomou a si o encargo de designar o pessoal docente, de organizar e dirigir o ensino. Seus trabalhos estão em últimos retoques; o sistema é fácil e principalmente prático, resultado da longa e esclarecida experiência.

A nomeação do professor Pardal para o cargo de diretor, "sem prejuízo do magistério público, que o mesmo exerce", foi bem recebida por colegas professores que registraram a satisfação no periódico $A$ Verdadeira Instrução Pública (15 ago. 1872). A folha, ao assinalar a gratidão à Sociedade da Infância Protetora pela distribuição de vestuário às crianças pobres para frequentarem a escola, agradece também à Câmara Municipal "pela consideração que nos dá incumbindo da direção de suas escolas a um dos nossos mais estimados colegas, o prestimoso professor C.M. de Faria Pardal”.

Os redatores ressaltam que, naquele momento, a escolha de Pardal era muito significativa. Fato que tem a ver com a agitação inerente da época e da qual Pardal também teve sua parcela de participação ao ser, por exemplo, signatário do Manifesto dos Professores Públicos Primários da Corte. Agradecem à Câmara pela sensatez de não acompanhar a opinião daqueles que "pensam que é desautorando o professorado que se há de conseguir reformar a instrução pública”, uma alusão aos debates e tensões que estavam ocorrendo naquele período, entre os quais aqueles que diziam respeito à outra folha $A$ Instrução Pública dirigida por Alambary Luz.

Com efeito, não era difícil encontrar entre tantos cavaleiros ilustrados no magistério particular, algum especialista que viesse com todo o prazer dar direção aos trabalhos das escolas municipais. Nem se poderia com justiça censurar a escolha por ser fora do magistério público. Porém vir escolher o diretor no nosso grêmio, foi manifestar 
ao público o desejo sincero de dar ao magistério público uma consideração que os poderes do Estado não lhe teriam por certo concedido (A Verdadeira Instrução Pública, 15 ago. 1872).

Os redatores procuravam tornar a nomeação de Pardal um reconhecimento ao magistério público e, sobretudo, àqueles que se mobilizavam e se organizavam. Ao assinalarem sua competência no ensino e o domínio de saberes pedagógicos também destacavam que Pardal fazia parte da categoria que estaria sendo ludibriada pelos governantes. Nesse aspecto, a última frase também emerge em tom provocativo. Os professores alegavam que os "poderes do Estado" não teriam concedido tal honra e apontavam de tal forma os embates entre os poderes do Estado e os da Câmara Municipal. As tensões ficam evidentes no discurso proferido pelo presidente da Câmara Municipal, Adolpho Bezerra de Menezes, por ocasião da inauguração da Escola Municipal São José, em 1874 ( $A$ Instrução Pública, 13 set. 1874 e Diário do Rio de Janeiro, 09 out. 1874):

Vossa Majestade, que já tem, certamente, pesado a necessidade e grandíssima vantagem de confiar ao elemento municipal a honrosa coparticipação em sua elevadíssima missão, não se tem por momento demorado ante o dizer pouco pensado de que as municipalidades estão decaídas, desmoralizadas por si mesmas .

Bezerra de Menezes atribui a imagem decaída da municipalidade à pouca reflexão e que, se ela assim fosse, seria motivo ainda maior para os poderes públicos elevá-las e moralizá-las:

Deem-lhe o que lhes tiraram, e o que lhes falta; deem-lhes a ação e o poder, independência e responsabilidade moral, e tenhamos por certo que, Lázaro ressuscitado, ostentará o vigor de suas forças.

A inação voluntária e forçada é como o trabalho material - absorve e gasta a energia vital; e as faculdades da alma, sopesadas pela indiferença, dormem em sono profundo, deixando apenas perceber, por algumas raras e inúteis manifestações, suas secretas virtudes.

Só a regeneração do elemento municipal, constituindo centros múltiplos de atividade, terá o poder de quebrar a inação - de apagar a indiferença e de plantar o estímulo no coração do povo brasileiro. 
O discurso, por meio de um evento bastante propício, a inauguração de uma escola com presença de D. Pedro II, buscava o reconhecimento da Câmara Municipal como órgão indispensável no progresso do país pela promoção da marcha do povo brasileiro, estagnado pela inércia e indiferença. A Câmara Municipal advogava para si outra imagem, a de ser o "melhor auxiliar de Vossa Majestade" na difícil tarefa de dirigir a sociedade brasileira.

Figura 33 - Escola Municipal de São José

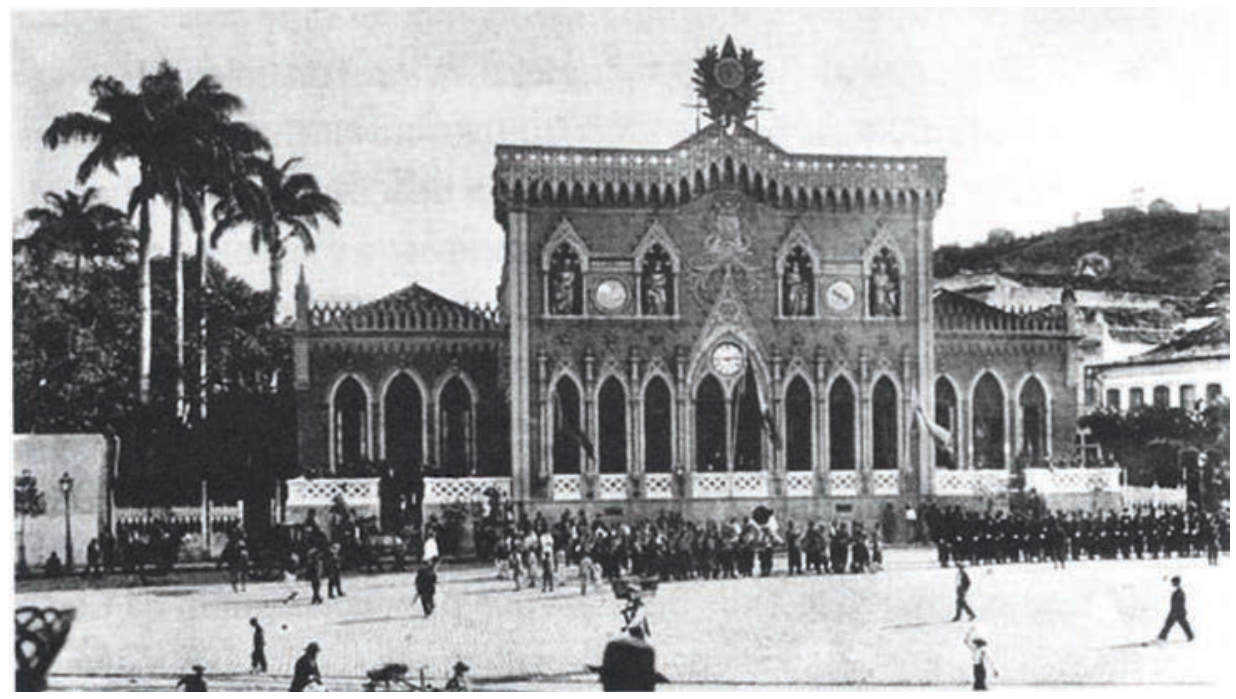

Fonte: Schueler e Gondra (2008).

A nomeação de Pardal, portanto, teria sido por reconhecimento de sua atuação no magistério público, mas também possui forte relação com as disputas de poder entre Estado e Câmara. O Estado poderia não conceder a Pardal tamanha honra, em razão da desvalorização da competência do magistério público ou de seu envolvimento com as manifestações docentes, mas essa mesma postura não procederia quanto aos poderes da Câmara, com os quais Pardal estaria envolvido por questões político-partidárias. Desse modo, apesar da experiência e sabedoria sempre ressaltadas do professor, é possível adicionar mais alguns critérios no que diz respeito às condições de nomeação, que podem ser inferidas nos artigos que tratam da sua exoneração em 1878 e 1879. Ambas teriam sido políticas. Cabe ressaltar que no mesmo mês de inauguração da Escola de São Sebastião tiveram lugar as eleições primárias, na qual Pardal foi candidato a eleitor. $\mathrm{Na}$ apuração 
final, conforme já mencionado, Pardal ficou em $6 .^{\circ}$ lugar entre os eleitos, com 736 votos. $O$ primeiro colocado teve 751 votos, o que mostra uma pequena diferença de votos (Correio do Brasil, 03 set. 1872).

No discurso de inauguração, Ferreira Vianna assinalou que, no âmbito pedagógico, os saberes a serem ensinados na Escola de São Sebastião compreendiam: instrução elementar, religião, desenho linear, noções de geografia e música vocal. A inserção de desenho linear no programa condiz com a prática de Pardal de lecionar a matéria na escola primária de Santa Rita, mesmo sem fazer parte do programa oficial.

A “instrução elementar” referida por Ferreira Vianna pode ser vista no programa, baseado no sistema de Rapet, enviado por Pardal para o inspetor geral da instrução na Corte. Ao analisar o relato do inspetor pernambucano Uchoa Cavalcanti, Schueler e Gondra (2008) afirmam que as escolas municipais visitadas por ele

[...] foram positivamente destacadas não apenas pelo aspecto moderno e grandioso da arquitetura (os "palácios escolares"), mas pela adoção de novos métodos e programas de ensino, nos quais surgiam alguns elementos da modernidade pedagógica (Nunes, 2000): a adoção do ensino seriado e graduado em três anos ou séries, das classes simultâneas e da forma escolar organizada sob um novo modelo com novos espaços tempos e modos de funcionamento escolar. Modernidade que também implicava em um único prédio escolar, específico para a instrução de crianças de ambos os sexos; vários professores, homens e mulheres inclusive um especialmente destinado ao ensino de música; a presença de uma hierarquia na gestão do ensino e de novas funções no espaço escolar (diretor, inspetor, professor, bedéis, servente, jardineiro) (p. 441-442).

Para colocar em prática o programa, Pardal contava com uma equipe que incluía, segundo edições do Almanak Laemmert: primeiros professores, segundos professores, professor de música, professor de curso noturno, bedéis, servente e até um jardineiro. A seleção de professores também estava sob os cuidados de Pardal que divulgava, em jornal de grande circulação, a realização de concurso, seguindo o mesmo processo usado pela "instrução pública”. O programa do concurso contava com dez itens entre os quais, desenho linear, cosmografia, geografia e pedagogia. Os candidatos também deveriam apresentar título de capacidade profissional expedido pela Inspetoria. 
Um artigo de Augusto Cony em $A$ Instrução Pública de 5 de janeiro de 1873, acerca dos exames da Escola de São Sebastião, relata que "O corpo profissional está superior às necessidades do ensino, mas não é só isso que tem feito medrar o trabalho, é o estímulo, o incentivo, a distribuição igual de favores com que sabe animá-lo o seu diretor". Relata também que a professora Joanna Margarida da Silva subiu à tribuna $\mathrm{e}$

[... em bem delineado discurso, expôs que ao diretor desta escola se devia o resultado favorável que o auditório tinha presenciado, que nas lutas da inteligência suas companheiras muito a tinham auxiliado na execução do plano de ensino, posto em prática, e que a dedicação do Sr. inspetor geral era o ponto de onde tinham dimanado todos os esforços empregados ao bom êxito de tão justa causa.

Cony expõe que várias professoras a sucederam na tribuna e "nada deixaram a desejar”. Depois, subiram os professores, entre os quais Dr. Navarro que "em elegante frase e bem formulados pensamentos mostrou-se igualmente acima do cargo que ocupa”. O diretor Pardal também fez seu discurso, após a execução do hino nacional.

[...] subiu à tribuna o diretor deste estabelecimento, e em um discurso cheio de animação, expôs o que se tinha passado nas aulas no espaço de quatro meses; depois dirigindo-se ao distinto inspetor geral das escolas municipais, o Sr. Dr. Antonio Ferreira Vianna, fez a justiça aos merecimentos desse senhor, que não tem poupado sacrifícios em levar a efeito a obra da educação da mocidade.

Cony, nesse momento, assinala que Pardal, com "experiência de 35 anos de serviço público", sabia "que mais vale a quem se preza uma palavra de louvor publicamente dita, do que sórdido interesse pecuniário". O comentário de Cony soava bastante político, colocando em evidência as estratégias do discurso que poderiam ser lançadas em situações públicas para estabelecimento ou fortalecimento de relações.

No entanto, Pardal também possuía críticas ao modelo das escolas municipais. Quanto aos prédios, um ofício assinala que Pardal havia se reunido com o Inspetor Geral da Instrução na Corte (que não era o mesmo Inspetor das Escolas Municipais), ocasião na qual manifestou as suas ideias "conforme o pensamento" daquela autoridade, "a respeito da necessidade de multiplicar-se o número de 
escolas públicas de instrução primária em ordem a satisfazer às exigências deste Município". No documento, o professor não poupou críticas aos prédios das escolas que dirigia:

O sistema inaugurado de grandes edifícios, além de ser sobremodo dispendioso apresenta alguns inconvenientes que seria de grande vantagem remediarem-se. Entre eles sobressaem: $10^{\circ} \mathrm{A}$ falta de acomodações nas próprias escolas para os professores respectivos; $2 .^{\circ} \mathrm{A}$ existência de duas escolas que se estão prontificando, embora de custosa construção e ainda mesmo quando seja construída uma dessas em cada Freguesia, não comporta o grande número de alunos que nelas tenham de se matricular; $3 .^{\circ} \mathrm{A}$ grande distância em que ficam estas escolas dos pontos mais afastados das respectivas Freguesias (AGCRJ, códice 10.4.19, 22 nov. 1872, f. 119).

O professor defendia que, em vez de se construir uma grande escola, seria mais proveitoso construir três ou quatro menores em pontos equidistantes da freguesia, com moradia para o professor. Dessa forma, "ter-se-ia aliado a economia pública com a comodidade e facilidade do ensino, fiscalização e muitas outras vantagens que resultam do sistema de divisão do trabalho". Assim, Pardal enviou ao Inspetor Geral um plano de construção de modelos de escolas menores, com orçamento, feito pelo engenheiro Rocha Fragozo, a seu pedido. O professor alegava que o trabalho projetado satisfazia "a necessidade desejada, além de oferecer uma bela fachada, em harmonia com o fim a que se destina e o embelezamento desta cidade". A agência do professor - que também ocupava uma posição de autoridade destacada, em razão da direção das escolas municipais - no sentido de aumentar o número de escolas primárias, demonstra que, mesmo após ter alcançado um posto maior, em outra esfera da administração pública, Pardal continuava a preocupar-se com a disseminação da instrução por meio das escolas públicas da Corte geridas pelo Estado Imperial. Embora já ocupasse o cargo de diretor das escolas municipais, o ofício foi assinado de sua antiga posição:

Persuadido de que, na qualidade de Professor da $1^{\text {a }}$ Escola pública da Freguesia de Santa Rita cumpro um dever apresentando esse trabalho, tomo a liberdade de pedir a V. Ex.a a sua poderosa intervenção, certo de que V. Ex.a prestará um grande serviço a Instrução pública deste Município concorrendo para a realização dessa ideia (AGCRJ, códice 10.4.19, 22 nov. 1872, f. 121). 
O fato de criticar os prédios das escolas municipais, muito elogiados pela sua modernidade e grandeza, em um momento em que era diretor das mesmas, denota que Pardal, apesar de ligado politicamente à instância responsável por elas, mantinha sua autonomia intelectual nas questões educacionais. A mesma postura se dava a respeito das carteiras escolares que poderia ter relação com a emergência e constituição de uma indústria escolar. Vidal (2005) assinala que o paulatino processo de incorporação de vários objetos ao fazer escolar estimulou tanto a importação de objetos da Europa e dos Estados Unidos da América quanto a produção nacional. Nesse sentido, foi possível observar o próprio professor Pardal fazer uma espécie de "propaganda" indireta acerca das escrivaninhas e bancos de Roberts dos Estados Unidos que ele mesmo havia examinado na "casa de Generoso Estrella” onde estavam expostos (AGCRJ, códice 10.4.19, 1872, f. 57). A casa de Generoso Estrela, situada na Rua do Ourives, n. ${ }^{\circ}$ 61, constava no Almanak Laemmert de 1872 na lista de Armazéns de gêneros norte-americanos e informava que o $\mathrm{Sr}$. Generoso possuía longa prática no ramo, viajando com frequência para Europa e Estados Unidos, assim como no Brasil, para "garantir o bom sortimento" da casa.

Segundo Alcântara (2014) a escola obrigatória e de massa movimentou o mercado e a economia, acionando mediadores e tradutores culturais e diferentes indústrias:

A quantidade expressiva de catálogos de mobiliário escolar e solicitação de patentes dá uma dimensão da relevância que as indústrias e fábricas de mobiliário escolar tiveram para o suprimento material da escola e, como corolário, para sua expansão. Também, elucida o quanto a escola foi um consumidor importante para a expansão desta atividade econômica (p. 163).

Em defesa da aquisição dos bancos de Roberts, Pardal critica até mesmo os bancos adotados na Escola Municipal de São Sebastião, que eram para seis ou sete meninos e ainda com o tampo fixo, impedindo a passagem durante o processo de escrita. Pardal alegava que "muito ganharia a boa disciplina, higiene e mesmo o ensino com o isolamento dos meninos, ou quando muito, que não fossem tais escrivaninhas e bancos para mais de 2 meninos" (AGCRJ, códice 10.4.19, 1872, f. 57).

O professor anexou ao ofício um prospecto intitulado "Novas carteiras ou escrivaninhas de Roberts para Colégios”, o qual fornecia sete razões para a superioridade das carteiras: eram muito elegantes na aparência; fortes e dura- 
douras, trazendo grande economia de espaço; possibilidade de entrar e sair delas com a maior facilidade; promoviam a saúde e o conforto; davam espaço para ler de pé, recitar e fazer exercícios ginásticos; tornavam as salas de aula belos salões espaçosos e cômodos para preleções e uso de adultos.

A propaganda eloquente e atraente pode ter provocado o interesse de Pardal em interceder pela aquisição de novas carteiras, em razão das condições da mobília da escola de Santa Rita que foram relatadas pela Comissão Visitadora das escolas e que constam no capítulo I. Os argumentos do prospecto eram bastante convidativos pela promessa de elegância, durabilidade, higiene e praticidade. Tal publicidade se articula com as reflexões de Alcântara, que assinala que o mercado cria objetos de desejos para a escola, tendo as Exposições Universais como importante espaço de exibição e o "Estado como comprador privilegiado" (2014, p. 81).

Durante a gestão de Pardal, a equipe da Escola São Sebastião, listada pelo Almanak em 1873, manteve-se nas escolas municipais, com exceção de um professor, Manoel dos Santos Marques. Com a inauguração da Escola Municipal de São José, alguns professores foram transferidos, como o 2. ${ }^{\circ}$ professor da de São Sebastião, Antônio Francisco de Castro Leal Júnior, que era “tenente honorário do exército”, que passou a ocupar o cargo de $1^{\circ}$ professor na Escola de São José. Eram professores que já tinham experiência na Escola Municipal e poderiam ajudar ao diretor Pardal a manter o tipo de trabalho pedagógico defendido por ele. Cabe ressaltar que Pardal pretendia, segundo jornal A Instrucção Pública, introduzir um novo método de ensino na Escola de São José

[...] que consiste em dividir os alunos na ocasião dos trabalhos em três turmas, para o que se acham as linhas de bancos convenientemente colocadas: a turma do centro ocupar-se-á em trabalhos de caligrafia, enquanto que a da direita se ocupará em leitura, e a da esquerda em matérias de cálculo, para o que existe a necessária pedra ( $A$ instrução pública, 13 set. 1874).

No entanto, no relatório do ano de 1874, o Ministro do Império João Alfredo Correa de Oliveira assinala que o regime seguido na Escola de São José era o mesmo da de São Sebastião, onde o ensino era simultâneo. O artigo assinala também que em 1874 estavam matriculados na Escola de São Sebastião, nas aulas diurnas, 340 meninos e 212 meninas, mas efetivamente haviam frequentado cerca de 200 e 130, respectivamente. Nas aulas noturnas, a matrícula era de 141 
alunos com frequência entre 40 e 45 . No caso da Escola de São José foram matriculados 308 meninos e 246 meninas. Quem eram os alunos da escola? “Todas aquelas crianças que representam verdadeiramente o elemento das classes mais necessitadas e que ainda não há muito tempo se viam privadas de receber o pão do espírito por falta de meios" (Diário do Rio de Janeiro, 10 dez. 1873).

Os resultados dos trabalhos realizados eram cuidadosamente exibidos em sessões públicas de exames, sendo vários registrados pelos jornais da época como o Diário do Rio de Janeiro (10 dez. 1873), que relata:

Parece-nos poder assegurar que poucas ocasiões se terão apresentado em que o ensino primário tenha entre nós exibido provas de uma tão variada distribuição de conhecimentos, ao mesmo tempo úteis e recreativos, como os que observamos nos discípulos da escola municipal de S. Sebastião.

Além da leitura, escrita e contabilidade, incluindo o sistema métrico, em que tanto os meninos com as meninas se mostraram sobremodo instruídos, notamos a sua aplicação no desenho linear, na etimologia e sintaxe gramatical, declaração e princípios de música e canto.

Segundo Antonio Ferreira Vianna, o trabalho realizado era de uma autoridade profissional "consolidada por mais de 40 anos de magistério, laureados por galardões e recompensas do governo imperial”. O trabalho configurava uma espécie de "escola-exposição", como uma vitrine pedagógica, em razão das visitas que a escola recebia e do destaque na Exposição Universal de 1876:

Os louvores que as escolas municipais de S. Sebastião e de S. José hão merecido no país, dos inspetores da instrução pública da corte, de visitantes os mais ilustres, assim nacionais como estrangeiros, e o glorioso prêmio que alcançaram na Exposição Universal de Filadélfia, são devidos só a dedicação e perícia de seu diretor (O Cruzeiro, 15 nov. 1878).

As escolas municipais também ganharam uma menção honrosa na Exposição Nacional de 1875, segundo Almanak Laemmert de 1876. O bom funcionamento da escola rendeu aos seus empregados uma bonificação pelos serviços prestados, como fica evidenciado no ofício do jardineiro que, excluído do grupo recompensado, também alegava merecer o prêmio: 
Illmo exmo sr presidente e mais membros da I. C.M. da Corte

Diz Antônio João Christovão, jardineiro das duas escolas municipais, que tendo sido contemplados todos os empregados das referidas escolas municipais com uma remuneração pelos serviços prestados as mesmas escolas; acontece que, o sup. ${ }^{e}$, foi excluído dessa prova significativa de bons serviços e como o sup. ${ }^{e}$ tem consciência de que os seus, embora de natureza diversa, tem todavia merecimento pela perseverança com que trata e conserva em perfeito estado essa parte tão importante dos dois estabelecimentos, que tanto concorre para o seu aformoseamento; e tornando-se além disso odioso aos olhos de todos esta exclusão; vim, portanto, respeitosamente reclamar com a maior consideração de V. Exs. mais esta prova de justiça que a I.C.M. costuma distribuir a todos os seus empregados honestos que cumprem seus deveres; e por isso

P.e espera que a I.C.M., tomando na devida consideração este seu apelo, se dignara mandar que ao sup. ${ }^{e}$ seja concedida uma gratificação igual aos demais empregados (AGCRJ, 15.4.35, f. 524/1/1877).

O pedido do jardineiro foi indeferido, desconsiderando seu apelo de "empregado honesto" que cumpria seus deveres e que contribuía para o "perfeito estado" e aformoseamento dos estabelecimentos. Algo parecido se deu com a exoneração de Pardal, destituído do cargo apesar de ser considerado um professor ilustre que também cumpria seus deveres.

As observações proferidas por Ferreira Vianna, publicadas em $O$ Cruzeiro, ocorreram diante da exoneração de Pardal do cargo de diretor, o que provocou grande indignação ao inspetor e certa agitação na imprensa. O periódico $A$ Reforma - Órgão Democrático (16 nov. 1878) publicou uma crônica sobre o modo como os conservadores "governam a sua família política" e afirmou que a exoneração se deu porque os vereadores da Câmara Municipal queriam "sangue novo". Acusavam de demitir o diretor das escolas "por ser velho e ter-se recolhido à reserva, embora continue como conservador e leve à urna o voto no dia da eleição". O jornal assevera que os vereadores conservadores estavam "aplicando um sistema de demissões dos próprios amigos que não deixa de ter interesse de ser conhecido." E que o fato "é útil para a história apreciar-se nos atos a índole e as tendências desse partido". Para o lugar de Pardal foi nomeado um jovem pertencente à milícia ativa que trabalhava na porta da igreja e nas juntas municipais, tendo sido também subdelegado. Assim "despediram o correligionário velho, e entregaram ao moço com a direção da escola os $2 \$ 000$ de ordenado". 
O inspetor das escolas municipais, Ferreira Viana, criticou a decisão e também pediu exoneração, segundo ofício publicado no jornal $O$ Cruzeiro (15 nov. 1878). Nesse documento, ficamos sabemos quão antiga é a relação dos dois, pois nele Ferreira Vianna conta a "honra de ter sido discípulo" do professor Pardal e afirma que suprimir a diretoria "seria privar organismo escolar do espírito que o anima”.

O ofício aparece publicado no interior da ata de uma sessão da Câmara Municipal de 14 de novembro de 1878 e as poucas opiniões que estavam registradas mostram que não havia unanimidade no procedimento. Um dos vereadores, Amaro de Moraes, asseverou que se estivesse presente na sessão que aprovou a exoneração teria sido contrário "tanto mais que resolveu-se esta matéria sem ouvir-se o inspetor geral das escolas". Outros vereadores propuseram não aceitar a exoneração de Ferreira Vianna, sugestão que foi aprovada. Meses depois, o periódico $O$ Repórter (09 fev. 1879) informava a reintegração de Pardal ao cargo de diretor das escolas municipais, sem apontar os motivos. Talvez a pressão de Ferreira Vianna e as discordâncias no interior da Câmara tenham feito os vereadores reverem a decisão. No entanto, logo em seguida, em 16 de fevereiro de 1879 ( $O$ Repórter), era Pardal quem pedia exoneração.

\section{"Outros tempos, outras necessidades": as circunstâncias de aparecimento das ideias de Rapet no Brasil}

Lembrando-nos do antigo adágio - outros tempos, outros costumes, o qual tomamos a liberdade de substituir por - outros tempos, outras necessidades; interpretando que os maus resultados, que dizem existirem, estavam na organização do ensino, e não em seus executores; instado ainda pela força das circunstâncias; metemos mãos à obra na feitura de um programa que mudasse a face do ensino elementar, arriscando-nos a animadversão dos que não pensassem como nós. Professor Augusto Candido Xavier Cony (A Instrucção Pública, 17 nov. 1872)

Em meio à recente nomeação para diretor, o debate em torno da circular expedida pela Inspetoria Geral, a convocação das Conferências Pedagógicas, as críticas em torno da falta de programa e quadro de horários, Pardal aparece com seu programa adotado nas escolas municipais. A primeira versão consta no relatório da Inspetoria referente ao ano de 1871, mas assinado em 31 de outubro de 1872 . O relator inspetor geral dizia que havia "acabado de receber", o que 
significa que o programa havia sido provavelmente enviado no próprio mês de outubro de 1872.

Trata-se do mesmo relatório que traz as respostas dos professores à circular datada de 13 de julho de 1872 . Tal circular ordenava que "cada professor remetesse um programa para o ensino das matérias que constituem o ensino primário do primeiro grau, a fim de se regularizar o mais possível o serviço diário das escolas respectivas" (Resposta coletiva dos professores e professoras à circular da Inspetoria Geral, 1872). As respostas foram enviadas individualmente por vários docentes e coletivamente por um grupo de 35 professores e professoras. O professor Frazão foi o relator da resposta, cujo texto possuía um tom reivindicatório. A introdução marcava que o texto era um prova dos esforços para atender ao inspetor geral e que para tal "celebraram muitas conferências, nas quais foram sempre animados do melhor desejo de acertar”. Assim, estudaram "coletivamente as variadas questões que se prendem ao assunto, a fim de que as luzes e experiência de uns suprissem o que por ventura pudesse faltar aos outros".

Do grupo igualmente fazia parte o professor Pardal, que pode ter contribuído para disseminar o conhecimento em torno de Rapet entre os colegas. No entanto, na resposta elaborada coletivamente, Pardal tinha uma restrição quanto ao aspecto da "distribuição dos trabalhos e do tempo" e por isso, nesse ponto, apresentou uma resposta separada.

O programa das escolas municipais foi publicado em A Instrucção Pública (03 nov. 1872), com uma introdução explicativa redigida pelo professor Augusto Cony:

Trouxe-nos à imprensa o trabalho do nosso ilustre colega, diretor geral da Escola de São Sebastião, o Sr. Candido Matheus de Faria Pardal.

A instâncias nossas concedeu-nos esse senhor o seu importante trabalho, já adoptado naquele estabelecimento de instrução, permitindo-nos a sua publicação neste hebdomadário.

Cony ressalta que a bem "delineada obra" era uma honra que cabia a Pardal, que estava às portas de sua aposentadoria, pois já tinha 35 anos de magistério, e que "revertendo sobre a classe dos professores públicos, fazia encher de orgulho aos seus membros". Ao dizer que deveria partir da "nossa pena” e não na do "robusto escritor", o artigo conclamava os professores a se engajarem na "reforma do ensino" traduzida na elaboração de um programa para as escolas 
da Corte. Argumentava que, pelo fato do Império ter os olhos voltados para os professores da capital, "as províncias deste nobre e rico Império contam conosco; devemos-nos mostrar dignos por mais este motivo de apreço que merecemos e devemos ter". O professor também redigiu uma frase no decorrer do artigo que ilustra bastante o modo como a categoria se reconhecia: "Contamos com nossos colegas, os valorosos lidadores nas lutas intelectuais; eles não abandonarão tão justa e nobre causa”.

O trabalho nas escolas municipais também fez parte do relato publicado em A Instrucção Pública (05 jan. 1873) acerca da festa de encerramento das atividades do ano de 1872 na Escola Municipal de São Sebastião. Quem assina o relato é o próprio professor Cony, que não deixa de proferir elogios e de enfatizar que o sistema utilizado na escola era o de Rapet: "trabalho de 8 anos consecutivos de 1863 a 1871, e apreciado pelos maiores pedagogistas modernos, como, entre outros, o diretor da escola normal de Melun, o ex-diretor da escola normal de Versailles, o inspetor da academia de Douai em Laon” (p. 4). As informações trazidas sobre o assunto por Cony, em mais um de artigo na folha, demonstram que o professor tinha conhecimento dos debates em torno da circulação das ideias de Rapet na própria França.

Quais eram as questões existentes na época em torno do assunto na Corte, no que concerne às normas, aos relatórios oficiais e aos debates, que forneceram a Pardal o destaque dado a seu trabalho? No âmbito jurídico, as normas que estavam em vigor e que de algum modo também diziam respeito aos conteúdos a serem ensinados e à carga horária escolar remetem a três tipos de distintos alcances: o nacional, o municipal e o institucional. Em 1827, a Lei Geral de Ensino estabeleceu os saberes a serem ensinados em dois artigos:

Art. 6. Os professores ensinarão a ler, escrever, as quatro operações de aritmética, prática de quebrados, decimais e proporções, as noções mais gerais de geometria prática, a gramática de língua nacional, e os princípios de moral cristã e da doutrina da religiáo católica e apostólica romana, proporcionados à compreensão dos meninos; preferindo para as leituras a Constituição do Império e a História do Brasil.

$[\ldots]$

Art. 12. As Mestras, além do declarado no Art. 6, com exclusão das noções de geometria e limitado a instrução de aritmética só as suas quatro operações, ensinarão também as prendas que servem à economia doméstica; [...]. 
O Regulamento da Instrução Primária e Secundária da Corte de 1854 apresentava um regime de saberes um pouco mais detalhado.

Art. 47. O ensino primário nas escolas públicas compreende:

A instrução moral e religiosa,

A leitura e escrita,

As noções essenciais de gramática,

Os princípios elementares da Aritmética,

O sistema de pesos e medidas do município.

Pode compreender também:

O desenvolvimento da Aritmética e suas aplicações práticas, A leitura explicada dos Evangelhos e notícia da história sagrada,

Os elementos da historia e geografia, principalmente do Brasil,

Os princípios das ciências físicas e da história natural aplicáveis aos usos da vida, A geometria elementar, agrimensura, desenho linear, noções de música e exercício de canto, ginástica, e um estudo mais desenvolvido do sistema de pesos e medidas, não só do município da Corte, como das províncias do Império, e das Nações com que o Brasil tem mais relações comerciais.

Art. 48. As escolas públicas primárias serão divididas em duas classes:

A uma pertencerão as de instrução elementar, com a denominação de escolas de primeiro grau.

As outras de instrução primária superior com a denominação de escolas de segundo grau.

Art. 49. O ensino nas de primeiro grau será restritamente o que se acha marcado na primeira parte do Art. 47: nas do segundo grau compreenderá demais as matérias da segunda parte do mesmo Artigo, que por deliberação do Governo, sobre proposta do Inspetor Geral, e ouvido o Conselho Diretor se mandarem adoptar.

Art. 50. Nas escolas para o sexo feminino, além dos objetos da primeira parte do Art. 47, se ensinarão bordados e trabalho de agulha mais necessários.

Poder-se-ão também ensinar as matérias da segunda parte do citado Artigo, que o Governo designar, sobre proposta do Inspetor Geral com audiência do Conselho Diretor, conforme as diversas localidades em que forem situadas a sua importância. 
No caso do Regimento Interno das escolas públicas de 1855, o documento ratifica os conteúdos estabelecidos no Regulamento de 1854 e normatiza o "horário dos trabalhos”, já citado no capítulo I.

Tais instruções definiam os saberes e os horários de funcionamento da escola, mas não quanto tempo o curso primário deveria durar, nem a repartição dos conteúdos ao longo do curso, a carga horária de cada um e a distribuição dos tempos de aula em cada dia. Por outro lado, o inspetor geral da instrução Eusebio de Queiroz afirma que havia sido feito um programa para uso nas escolas com base nas discussões de uma conferência convocada por ele (Relatório relativo ao ano de 1856). Mas, apesar das normas regulando saberes, horários e o programa formulado na gestão de Eusébio (1855-1863), o que se observa nos relatórios, na imprensa e na fala dos professores é que cada escola organizava os saberes de forma diferente e dava mais ênfase a um saber e pouco ou nada aos outros, fazendo com que não houvesse uniformidade no ensino, fato que era motivo de preocupação tanto para o governo quanto para os próprios professores.

O relatório apresentado à Inspetoria pela "Comissão visitadora das escolas públicas e estabelecimentos particulares”, formada pelos professores Philippe da Motta Azevedo Correa, José Manuel Garcia e João Rodrigues da Fonseca Jordão, acerca do trabalho realizado em 1873 , registra que:

Em geral os professores dão a umas matérias amplidão, que elas não devem ter, a outras quase que não contemplam o ensino; todas enfim, parece a comissão que deveriam ser ensinadas de outro modo e com mais proveito para o aluno. Os métodos não são uniformes, os processos parciais também diferem, enfim não há homogeneidade no ensino das diversas matérias, contra o preceito legal, de sorte que um aluno que passar de uma para outra escola encontra diferente método de ensino, o que se torna para ele um embaraço, e vai aumentar a dificuldade com que naturalmente luta.

$[\ldots]$

A tabela da distribuição do tempo e das matérias pelas diversas classes não é observada nem mesmo existe ela na maior parte das escolas; também do modo por que ela está organizada entende a comissão que serve antes de embaraço do que de proveito para o andamento regular dos exercícios escolares; nem mesmo está em dia com os compêndios em uso atualmente, pelo que carece de pronta e radical reforma (1873, A-B7-40, grifos nossos). 
O relato da comissão sinaliza que, passados vários anos, o problema persistia, mas não é claro quanto à existência de um programa oficial, embora afirme que a "tabela" não era observada e que carece de reforma, indicando, portanto a possibilidade de haver alguma orientação. Entretanto são enfáticos ao comentarem a falta de homogeneidade do ensino.

Uma questão importante para compreender o problema da relação entre tempo e distribuição dos conteúdos trata-se do tipo de método usado que, segundo a comissão, também não era uniforme. $O$ método geral de ensino deveria ser o método simultâneo, mas segundo a mesma comissão:

O método simultâneo, que é designado pelo artigo 73 do regulamento para ser seguido nas escolas públicas, está substituido em muitas delas pelo método misto, que é uma combinação do simultâneo e do mútuo, e que na verdade melhor se presta para as exigências e condições da generalidade de nossas escolas; não pareceu a comissão que ele fosse executado sempre com toda perfeição, nem tampouco o simultâneo [...] (1873, A-B7-53, grifos nossos).

[...] mas decretando isso não se forneceu às escolas públicas os meios indispensáveis para por em execução o referido método, que exige, além de quadros e modelos próprios, um número conveniente de adjuntos com os quais o professor divida o trabalho, de sorte que haja para cada uma turma de 20 alunos 1 professor ou adjunto (1873, A-B7-40, grifos nossos).

Pelo fato do Regulamento determinar que nas escolas públicas primárias o ensino deveria ser o simultâneo, o governo parecia esperar que a tabela de horário ou programa fosse elaborado com base nessa norma. No entanto, segundo os professores, esse tipo de ensino - e em decorrência, a tabela de horário - demandava materiais adequados para colocá-lo em execução, bem como um quantitativo de adjuntos. Como tais condições não existiam, o ensino simultâneo também não ocorreria como o esperado, assim como dificultava a tarefa de estabelecer um “programa-horário”, não obstante as tentativas já realizadas.

Apesar dos documentos discutirem a elaboração de um programa com tabela de horário como se fosse algo de conhecimento geral, o procedimento parecia não ser tão difundido assim, como fica explícito na fala do professor primário Antonio Estevão da Costa e Cunha. A confecção de um "programa-horário" minucioso, como nomeou o professor Costa e Cunha nas conferências, em que 
o professor soubesse de antemão pelas tabelas o que ensinar --"a tarefa de cada dia útil" -, consistiria em uma "novidade pedagógica" que poderia uniformizar o ensino primário nacional: "Bem se pode ver, por aqui, quanto é grande a importância que eu ligo a essa, para nós, novidade pedagógica” (1872-2A, A-B8-8).

O professor apresentou uma reflexão em torno de como a confecção de um programa deveria se dar para cumprir bem a tarefa e ressaltou o tempo necessário para elaborar um trabalho bem feito:

Senhor, tenho muita satisfação em servir cumprindo as determinações dos superiores, mas em servir bem. Queira V. Ex. conceder-me um ano para eu organizar e ensaiar o trabalho segundo a letra da circular, findo esse ano eu hei de voltar e dizer: eis o programa, agora respondo por ele (Relatório IGIPSC, 1872-2A).

Para corroborar a necessidade de tempo de reflexão, Costa e Cunha recorre ao próprio Rapet, ressaltando as condições de produção da obra do francês, o que sinaliza certo conhecimento em torno do assunto e as leituras às quais o professor tinha acesso:

O melhor trabalho que se conhece sobre o assunto é o do Sr. Rapet, que para completá-lo, empregou oito anos; note-se que foram precisos nada menos de oito compridos anos para levar a efeito a sua obra, e atenda-se mais que, além de muito prático na matéria, ele é ou era inspetor geral da instrução pública de Paris, e dispunha de todos os elementos que necessitasse, de quantos conselhos e professores quisesse ouvir, de quantas escolas houvesse mister para ensaios e experiência.

Repito pois: - E poderemos nós resolver tão importante questão sem tempo para detido exame e acurado estudo? (1872-2A, A-B8-8).

No entanto, para contestar possíveis argumentos a favor da adoção de um programa estrangeiro, o professor se posicionou energicamente:

E não se nos venha dizer que o trabalho já está feito pelo Sr. Rapet, que com algumas modificações o podemos adotar, isto é matéria que também demanda muita atenção e escrúpulo, para que não nos aconteça o que até agora temos visto com os regulamentos adotados, senão copiados (1872-2A, A-B8-8). 
O professor propôs a elaboração de um programa que pudesse ser usado em todas as escolas e que levasse em consideração vários aspectos, como os alunos, os professores, as peculiaridades do calendário brasileiro, sexo, localização da escola, entre outros.

Cumpre nesse programa atender a tanta cousa, tanta! Tais como a desigualdade da inteligência, aplicação e frequência dos alunos; tais como instabilidade dos dias feriados e festivos (festas móveis), os impedimentos inesperados do professor que não tem ajudante; tais como a necessidade que há nas escolas urbanas de certas matérias e nas suburbanas ou rurais de outras, diferença esta que vai também de escolas do sexo masculino às do outro sexo; tais como a falta de uma época determinada para matrícula, as exigências de pais ignorantes, a deficiência de auxiliares na altura de seu mister, etc. - que suponho não andar desacertado, lembrando o alvitre que constitui este parecer, que emito depois de muita reflexão e que submeto, respeitoso, ao juízo esclarecido de V. Ex. e do Ex. ${ }^{\circ}$ Conselho.

Embora criticasse a adoção do trabalho feito no exterior, o professor era favorável ao intercâmbio de ideias entre países e afirmava que "as nações mais adiantadas aprendem todos os dias umas com as outras" e, nesse sentido, enfatiza: "não censuro, pois, que tomemos ao estrangeiro o que for bom; mas só o que for e puder acomodar-se, depois de modificado, aos nossos usos e necessidades: - condeno, sim, a adoção de preceitos estranhos, inaclimáveis na nossa terra” (Relatório da IGIPSC, 1872-2A, anexo 8, A-B8-9).

O professor sugere aproveitar os programas existentes como os de Pardal, Cony e Alberto para serem examinados por uma comissão que deveria escolher "o que melhor se adaptar às necessidades do ensino primário":

Depois de aprovado pela inspetoria geral e o Conselho Diretor, será esse programa ensaiado nas escolas por espaço de um ano, findo o qual será discutido em outras conferências, e depois de se lhe fazerem as modificações que a prática aconselhar, se aconselhar, seja então definitivamente adoptado (Relatório da IGIPSC, 18722A, anexo 8).

O programa do professor Pardal, que aparece na resposta a circular de 13 de julho de 1872 para o ensino das primeiras letras nas escolas públicas, consistia no "método ou antes Cours d'études des écoles primaires publiques sous la direction 
de Mr. J.J. Rapet". ${ }^{3}$ Essa informação vai emergir com destaque e ser comentada durante as conferências. Phillippe da Motta assinala no parecer que o plano de estudos de Pardal também era adotado por outros professores que seriam "os melhores juízes nesse assunto".

Método ou sistema? Afinal, do que trata Rapet? O uso de termos diferentes pelos professores nos leva a fazer algumas interrogações. Seria uma apropriação do uso da palavra pelos próprios pedagogistas e autores de manuais franceses ou uma estratégia dos professores da Corte de legitimação de suas práticas? $\mathrm{Ou}$ como sinalizado no capítulo I, a falta de um limite de significação reclamada por Costa e Cunha em torno de vocábulos como "sistema" e "método"?

Anne-Marie Chartier (2007), ao discutir quais categorias adotar para ordenar o conjunto de livros de aprendizagem que compunham a coleção de Jean-Jacques Rapet, chama atenção para o problema do uso do termo "método" na França no século XIX. A autora alerta que "Vauclin designava todos os manuais como 'métodos.” A palavra, entre 1830 e 1840, aparecia somente em um terço dos títulos; no Segundo Império (1852-1870), na metade; e em dois terços entre 1870 e as leis Ferry.

Vê-se, assim, nesse momento, instalar-se um termo genérico que, na França, permanece em vigor. Um método é um conjunto de princípios e escolhas teóricas para guiar a ação, tal como expostos em um discurso (quer se trate do Método cartesiano, do Método experimental de Claude Bernard, ou do Método natural de Freinet); na escola, um método é um guia pedagógico, redigido para o professor. [...] Mas no uso que se impôs, a palavra "método" designa qualquer livro para o iniciante. Nos anos 1870, o uso oral relatado por Vauclin (o método Villemereux) apareceu na publicação: o método se apresenta com o nome de seu autor (Méthode Néel, Méthode Menet, Méthode Gédé, Méthode Cuissard). (Chartier, 2007, p. 96-97, grifos da autora).

Dessa forma, a autora assinala que se encontravam confundidos os princípios e o livro de aprendizagem em que eles eram colocados em prática e que, em razão disso, a "guerra entre os métodos" na França ocorreu por meio dos manuais. Segundo Chartier (2007, p. 106, grifo da autora), para Rapet, "os avanços metodológicos dos manuais só poderiam produzir seu efeito pela organização

${ }^{3}$ Resposta datada de 26 de dezembro de 1872 . O documento encontra-se anexado ao Relatório da IGIPSC de 1872. 
estruturada do currículo, um 'plano de estudo que fará com que os pais adquiram o hábito de trazer suas crianças na data certa'." Assim, conforme se "instalava essa rotina de ensino coletivo, mais os manuais definiam a duração ideal para repartir a carga de trabalho no tempo" (p. 108), aspecto do caso francês que pode ter chamado atenção dos professores primários brasileiros.

O sistema escolar, de acordo com Chervel (1990), desempenha na sociedade um papel de formar "não somente os indivíduos, mas também uma cultura que vem por sua vez penetrar, moldar, modificar a cultura da sociedade global" (p. 184). As disciplinas escolares e o modo como são operadas atuam nessa direção. São elas que, segundo Chervel, determinaram a divisão do grupo de alunos e sua repartição em classes por níveis. Divisão e repartição que também estavam presentes no plano de ensino das primeiras letras do professor Pardal.

\section{Jean-Jacques Rapet, suas obras e concepções atraentes}

Nós chegamos mesmo a pretender que o professor nasça, e não que ele se torne. Heresia manifesta. Repudiamos uma teoria que tenda a fazer crer que torna-se um mestre sem trabalho e sem esforço e que faça crer na inutilidade dos estudos para se aperfeiçoar e adquirir mais habilidade na arte que exerce.

Jean-Jacques Rapet

(Introdução ao livro de Charbonneau, Cours théorique et pratique de pédagogie)

O francês Jean-Jacques Rapet nasceu em Miribel, em 1805, e faleceu em 1882, em Paris. Sua trajetória foi marcada por diversas atividades na área educacional. Realizou viagem ao estrangeiro, onde esteve em contato com pedagogos alemães e suíços. No âmbito da formação docente foi nomeado por Guizot para o cargo de diretor da Escola Normal de Périgueux em 1833 e participou da comissão ministerial encarregada de reformar a formação de professores primários entre 1845 e 1848. Nomeado subinspetor primário em Paris, em 1847, depois inspetor, em 1850, tornou-se inspetor geral da instrução primária em 1861. Em 1872, aposentou-se com o título de inspetor geral honorário da instrução primária. Rapet atuou em três periódicos pedagógicos - Education, Bulletin de l'Instruction Primaire e Journal des Instituteurs - e constituiu uma coleção de livros de mais de cinco mil volumes que foram comprados pelo Estado em 1880 e colocados no fundo da biblioteca do Museu Pedagógico. Atualmente fazem parte do fundo da biblioteca do extinto INRP (Institut National de Recherche Pédagogique), que foi transferida para a Universidade de Lyon (Havelange et al., 1986; DuBois e Bruter, 2002). 
Quadro 26 - Algumas obras de Rapet e ano das edições localizadas durante o estágio de pesquisa na França

\begin{tabular}{|c|l|c|}
\hline N. & Título & Ano \\
\hline 1 & $\begin{array}{l}\text { Considérations sur l'éducation, suivies de l'exposé d'un plan propre a réunir les avan- } \\
\text { tages des éducations publique et particulière, sans en avoir les inconvénients }\end{array}$ & 1831 \\
\hline 2 & $\begin{array}{l}\text { De l'Influence de la suppression des tours dans les hospices d'enfants trouvés sur le } \\
\text { nombre des infanticides, par M. J.-J. Rapet; mémoire lu à l'Académie des sciences } \\
\text { morales et politiques, dans la séance du 11 octobre 1845 } \\
\text { Rapet, Jean-Jacques (1805-1882) }\end{array}$ & 1845 \\
\hline 3 & Notice sur la vie et les travaux de F. M. L. Naville & 1847 \\
\hline 4 & $\begin{array}{l}\text { Des conditions du bien-être pour les classes laborieuses et de l'influence qu'il exerce } \\
\text { sur la moralité }\end{array}$ & 1851 \\
\hline 5 & Principes de grammaire française & 1852 \\
\hline 6 & Cours élémentaire de langue française (livro do professor e do aluno) & 1852 \\
\hline 7 & Manuel Populaire de Morale et d'économie politique à l'usage des classes ouvrières & 1858 \\
\hline 8 & $\begin{array}{l}\text { Manuel de législation et d'administration de l'instruction primaire, ou Recueil des } \\
\text { lois, décrets, arrêtés, règlements, circulaires et instructions concernant l'instruction } \\
\text { primaire }\end{array}$ & 1862 \\
\hline 9 & Cours superieure de langue française (livro do professor e do aluno) & 1867 \\
\hline 10 & $\begin{array}{l}\text { Plan d'études pour les écoles primaires. Repartition de l'enseigment et emploi du } \\
\text { temps }\end{array}$ & $1 / 1876$ \\
\hline 11 & Cours d'études des écoles primaires & \\
\hline
\end{tabular}

Fonte: Quadro elaborado pela autora com base no levantamento realizado durante a pesquisa.

Os professores da Corte conheciam o Cours d'études des écoles primaires e o Manuel Populaire de Morale et d'économie politique à l'usage des classes ouvrières, como mostram os jornais e menções às obras durante as Conferências Pedagógicas de 1873. Mas é o Cours d'études, obra que também havia sido publicada no Journal des Instituteurs, que vai ficar em evidência durante o período das conferências. O Cours estava na lista de obras autorizadas para compor bibliotecas escolares francesas por um decreto de 1863 do Ministro da Instrução Pública, na época Gustave Rouland, ${ }^{4}$ no período do Segundo Império na França, que durou até 1870, quando teve início a Terceira República.

4 Extraído da lista de ministros da instrução organizada pelo antigo INRP (Institut National de Recherche Pédagogique), atualmente disponível em http://rhe.ish-lyon. cnrs.fr/?q=ministres-list. Acesso em: 14 fev. 2020. 
Na introdução do Cours d'études des écoles primaires, Rapet faz a apresentação da obra e explica o funcionamento do curso, atribuindo a ele a capacidade de resolver alguns problemas recorrentes nas escolas francesas. Embora tratasse de realidades distintas e de um quantitativo de escolas diferentes, alguns problemas eram semelhantes aos relatados pelos professores primários do Rio de Janeiro e de outras regiões do país.

Figura 34 - Capa do Cours d'Études (1871) - exemplar localizado na Bibliothèque Historique de la Ville de Paris

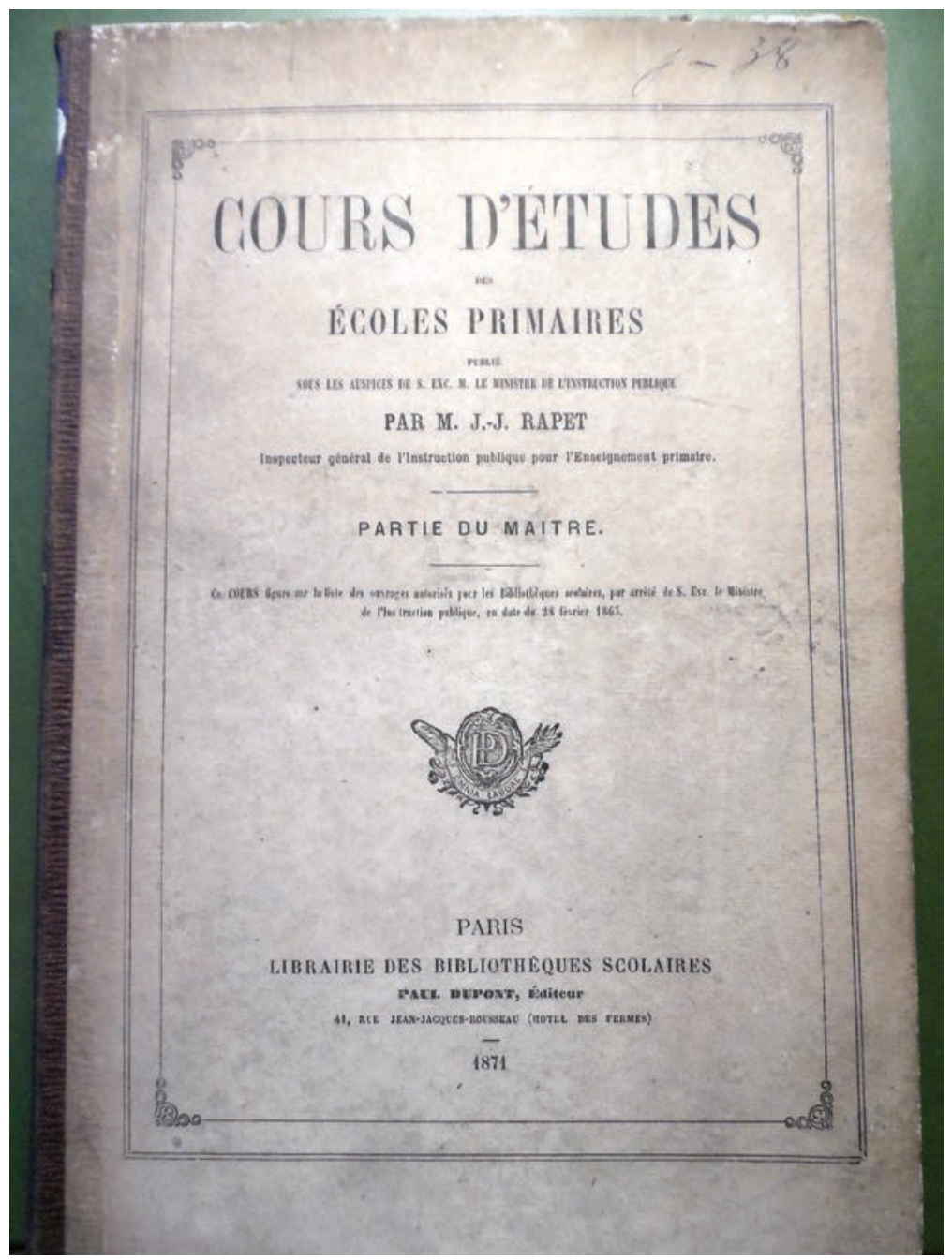

Fonte: Foto da autora. 
Uma das primeiras observações feitas era que o curso se destinava a escolas de um mestre: "Concebido especialmente em vista das escolas mais numerosas, ou seja, daquelas que são dirigidas por um único mestre, sem ajuda de um adjunto" (1871, p. 3, tradução nossa). ${ }^{5}$ O professor adjunto mencionado por Rapet não era o mesmo existente na Corte. No caso francês, o adjunto era um professor formado que auxiliava o professor regente da escola e na Corte, oficialmente, um aprendiz do ofício.

As estratégias discursivas de Rapet teriam chamado a atenção dos professores brasileiros que poderiam se identificar com o público alvo da obra, em que pesem as diferenças de realidade, com o argumento das experiências bem sucedidas de vários professores franceses: "Aqueles que ainda poderiam duvidar da possibilidade de colocar esse sistema em prática podem contar com a experiência dos milhares de bons mestres que já o seguem com tanto sucesso" (p. 3, tradução nossa). ${ }^{6}$ A experiência foi mencionada pelo professor Costa e Cunha, conforme levantado. Outra vantagem elencada por Rapet era a de que o sistema dava liberdade para os professores escolherem os livros, os métodos, a maneira de fazer as lições e explicar os assuntos, pois o Cours se limitava a dar a direção e mostrar a ordem que convinha seguir em cada ramo da instrução, tendo como objeto principal fornecer aos professores os exercícios e deveres a serem dados aos alunos durante e após as lições.

Nesse sentido, cabe destacar que em artigo sobre Rapet publicado em $A$ Instruç̧ão Pública (03 ago. 1872), intitulado "Cursos de estudos do Sr. Rapet" - uma tradução do título da obra francesa -, o professor Augusto Cony afirma que, quando na França o ensino primário era motivo de opiniões controversas e as pessoas mais ou menos "autorizadas" tentavam dar ao povo uma instrução "mais sólida”, "o inspetor geral da instrução pública deste país trabalhava no intuito de fazer extinguir as discórdias e apresentar uma obra que honrasse ao corpo profissional no ensino público, como se faz hoje entre nós". A obra "retribui exuberantemente os sacrifícios empregados" por Rapet que "deu à luz da publicidade" um "utilíssimo livro - intitulado - o livro do mestre". Interessante observar como o professor lidou com a tradução da expressão "Partie du maître"

5 No original: "Conçu spécialement en vue des écoles les plus nombreuses, c'est-à-dire de celles qui sont dirigées par un maître seul, sans le secours d'un adjoint".

6 No original: "Ceux qui pourraient douter encore de la possibilité de mettre ce système en pratique peuvent s'en rapporter à l'expérience des milliers de bons maîtres qui le suivent déjà avec tant de succès". 
que aparecia no livro original em francês ao final das explicações da titulação da obra, como pode ser visto na imagem anterior. Talvez, o "livro do mestre" trouxesse maior significação do que a "parte do mestre".

Os saberes que compunham o curso seguiam a norma oficial e Rapet os distribuiu por três anos: “Todos os ramos da instrução primária compreendidos no programa atual de ensino obrigatório são divididos, como acabou de ser dito, em três anos aos quais damos o nome de curso" (p. 3, tradução nossa). ${ }^{7}$ Rapet ofertava um modelo de distribuição dos conteúdos pelos três cursos, bem como das lições pelos meses, semanas, dias e horas.

Por meio do Cours, pretendia fornecer a tão almejada uniformidade do ensino reclamada pelo governo e pelos professores e também se apresentava como uma solução para um grande problema existente tanto no Brasil quanto na França: a irregularidade de frequência e a entrada dos alunos em qualquer época do ano. Para tanto, o uso do curso de Rapet levaria os pais a entenderem a dinâmica escolar:

Os pais, por sua vez, que não têm ideia da sucessão de lições em uma escola onde o ensino deve ser dado a toda uma divisão por vez, e que imaginam frequentemente que o que a criança não aprendeu em um dia, uma semana, ou um mês, ela poderá aprender no dia, na semana, no mês seguinte, os pais [...] verão eles mesmos que isto não é possível em um ensino metódico, que se dirige a todo um grupo de alunos; sua educação, nesta relação, se faz ao mesmo tempo que a de seus filhos (p. 10, tradução nossa). ${ }^{8}$

Embora os professores não mencionem a outra obra de Rapet chamada Plan d'études pour les écoles primaires. Repartition de l'enseignement et emploi du temps, sua leitura é referida no Cours d'études e traz importantes elementos para

7 No original: "Toutes les branches d'instruction primaire comprises dans le programme actuel de l'enseignement obligatoire sont divisées, comme il vient d'être dit, en trois années auxquelles on donne le nom de cours".

${ }^{8}$ No original: "Les parents, à leur tour, qui n'ont aucune idée de la succession des leçons dans une école où l'enseignement doit être donné à toute une division à la fois, et qui s'imaginent souvent que ce que l'enfant n'a pas appris un jour, une semaine, où un mois, il pourra l'apprendre le jour, la semaine, le mois suivant, les parents, [...], voient eux-mêmes que cela n'est pas possible dans un enseignement méthodique, qui s'adresse à tout un groupe d'élèves; leur éducation, sous ce rapport, se fait en même temps que celle de leurs enfants". 
pensar o modo como o inspetor francês construiu seu Cours com lições para cada dia do ano. Enquanto que o Cours d'études traz somente uma introdução antes do programa propriamente dito, o Plan d'études possui vários capítulos para fundamentar a forma como Rapet pensou a divisão das matérias e o programa de ensino para as escolas primárias, considerando suas peculiaridades. $\mathrm{Na}$ introdução, Rapet apresenta argumentos acerca da importância do trabalho elaborado e afirma que o plano havia sido reimpresso para atender ao desejo dos professores. Assinala igualmente, em tom de progresso, que a necessidade de cada escola ter um plano de estudos que atendesse aos imperativos do ensino começava a ser sentida: "Um plano de estudos é um guia que nos mostra cada dia a rota a seguir, e que, marcando o ponto aonde nós chegamos, nos lembra sem cessar o espaço a percorrer. É uma espécie de mentor que prevê as lacunas e as perdas de tempo" (1868, p. 5-6, tradução nossa). ${ }^{9}$

O livro Plan d'études encontrado na Bibliothèque Nationale de France é uma edição de 1868 - mas a obra data de 1859 (Jacquet-Francillon, 1999; DuBois e Bruter, 2002) - e é dividido em duas partes. Na primeira, Rapet tece uma discussão mais geral, comparando o ensino primário ao secundário, no que diz respeito à necessidade de um plano de estudos e à condição dos professores, bem como um plano deveria atender às necessidades do ensino. Na segunda parte, discute o plano de estudo em si, em que bases ele deveria estar fundamentado, o caso das escolas de um só mestre, as lições a serem dadas, as repartições do ensino, meios de resolver as dificuldades de um plano repartido para três cursos, a determinação dos cursos e de suas matérias, explicação dos quadros que resumem o plano, o quadro de emprego do tempo e a repartição do ensino nas escolas que dispusessem de um professor adjunto.

9 No original: "Un plan d'études est un guide qui nous montre chaque jour la route à suivre, et qui, en marcant le point où nous sommes arrivés, nous rapelle sans cesse l'espace à parcourir. C'est une espèce de mentor qui prévient les écarts et les pertes de temps $[\ldots]$ ". 
Figura 35 - Sumário do livro Plan d’Études (1868). Imagem de fotocópia digitalizada

\section{TABLE NES MATIĖRES.}

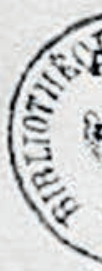

TF:

Pagos.

PREAIIERE PARTIE.

Cuyrzrñy I. Nècossité d'un plan d'études. Comparaison

Lil pristro'l'instruction primaire of l'instruction secondaire.

Cirspirne II. Différence de position des maltres dans l'ensoignement primaire et l'enseiguement secondaire.....

Citupirne III. Comment le plan d'études doit êtro approprié aux besoins des écoles.................... I

\section{UEUXIÈALE PARTIE.}

Cuaptrne I. Bases d'un plan d'études... ........... 33

Cinptrne II. Nécessité d'un aide dans les écoles dirigées pat un scul maltre........................

Chapitre III. Des leçons a donner aux jeunes enfants et des leçons a leur faire...................... 19

Cishpitre IV. Répartition des matières d'enseignement entre les trois divisions. . . . . . . . . . . . . . . .

Chaptrae V. Moyenz de résoudro les difficultés que peut présenter la répartition de l'enseignement en trois cours

Cinsptrke VI. Détermination des cours ou divisions el

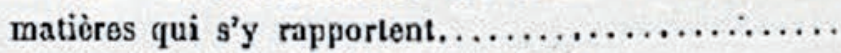

Ciraprta VII. Explications des tableaux qui résument le

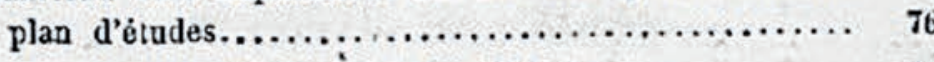

Cuspitae VIII, Tablean de l'omploi da temps.........

Chapithe IX. Répartition de l'enseignement dans les écoles pouryaes d'adjoints..................... 
Na discussão comparativa entre o ensino primário e o secundário realizada na primeira parte, ao colocar um tipo de ensino diante do outro nos dá a ver as diferenças, mas também o próprio modo como essas diferenças são constituídas a partir da referência ao outro. Para Rapet, a responsabilidade sobre os parcos resultados do ensino primário e os alunos saberem muito pouco em relação ao tempo que passavam na escola primária era atribuída aos métodos usados e aos professores. Porém, assinalava que os professores, por outro lado, alegavam muitas dificuldades:

Às dificuldades inerentes à educação, e que são, em todo estado de coisas, a consequência das falhas naturais da criança, se somam em efeito todas aquelas relacionadas às circunstâncias particulares nas quais encontram lugar os mestres encarregados da direção das escolas. Falhas de desenvolvimento intelectual de seus alunos que permanecem quase sem cultura até o momento em que chegam, porque eles não encontram recursos na família; irregularidade da frequência, fim prematuro de estudos, e, sobretudo abandono da escola durante uma parte do ano, o que faz perder, em grande parte, o fruto das lições precedentes; condição frequentemente deplorável das escolas, privadas da maior parte dos meios necessários ao sucesso de ensino; enfim, posição excessivamente penosa do mestre, quando está sozinho para dar instrução aos alunos de todas as divisões, e para satisfazer ao mesmo tempo às exigências multiplicadas da direção de uma escola: eis as sérias dificuldades e cujo valor não é sempre compreendido pelas pessoas estrangeiras à instrução primária (p. 8 , tradução nossa). ${ }^{10}$

${ }^{10}$ No original: "Aux difficultés inhérentes à l'éducation, et qui sont, dans tout état de choses, la conséquence des défauts naturels de l'enfance, s'ajoutent en effet toutes celles qui tiennent aux circonstances particulières dans lesquelles se trouvent placés les maîtres chargés de la direction des écoles. Défaut de développement intellectuel de leurs élèves qui sont restés presque sans culture jusqu'au moment où ils leur arrivent, parce qu'ils ne trouvent pas de ressources dans la famille; irregularité de la fréquentation, fin prématurée des études, et surtout désertion de l'école pendant une partie de l'année, ce qui fait perdre, en grande partie, le fruit des leçons précédents; condition souvent déplorable des écoles, où l'on est privé de la plupart des moyens nécessaires au succès de l'enseignement; enfin position excessivement pénible du maître, lorqu'ils est seul pour donner l'instruction aux élèves de toutes les divisions, et pour suffire en même temps aux exigences multipliées de la direction d'une école: voilà des difficultés sérieuse et dont la valeur n'est pas toujours suffisamment comprise par les personnes étrangères à l'instruction primaire". 
Depois de enumerar as dificuldades e a gravidade do problema, Rapet apresentou o "remédio", uma melhor direção aos esforços dos professores, os quais eram incontestáveis, mas às vezes pouco eficientes, e uma melhor organização dos estudos. Demarcava que, antes de saber como ensinar, era preciso saber o que ensinar, quando e a quem: "É preciso em uma palavra ter um plano de estudos e um programa detalhado de ensino" (p. 9, tradução nossa). ${ }^{11} \mathrm{O}$ sucesso da escola dependia de uma organização dos estudos e esta era a diferença entre o ensino secundário e o ensino primário. Mas Rapet advertia que estabelecer um paralelo entre os dois seria injusto, pois o ensino secundário tinha séculos de existência, enquanto que o primário ainda estava tateando: "O ensino secundário data de vários séculos, e ele com isso é formado de tradições que não existem na instrução primária; família, alunos, professores, todo mundo está acostumado com isso há muito tempo" (p. 27, tradução nossa). ${ }^{12}$ Mas ressalta a diferença no que concerne ao conhecimento da duração do tempo de estudos:

No ensino secundário, além disso, há uma duração de estudos determinada, o que não há no ensino primário. Quer que seus filhos façam estudos clássicos: ao colocar ele no colégio sabe quanto ele deve ficar e o que ele aprenderá. Coloque ao contrário seu filho em uma escola: você não sabe nada. Pode dizer que o deixaria aí tantos anos ou até certa idade; mas não sabe exatamente nem o que ele aprenderá, nem quantos anos deverá deixá-lo aí para que ele aprenda tal ou tal coisa (p. 11-12, tradução nossa).13

O controle do que era ensinado no secundário permitia saber quanto tempo durariam os estudos nesse grau, o que se contrapunha ao que ocorria no

${ }^{11}$ No original: "Il faut en un mot avoir un plan d'études et un programme detaillé d'enseignement".

${ }^{12}$ No original: "L'enseignement secondaire date de plusiers siècles, et il s'y est formé des tradictions qui n'existent pas dans l'instruction primaire; familles, élèves, maîtres, tout le monde y est accoutumé depuis longtemps".

${ }^{13}$ No original: "Dans l'enseignement secondaire, en outre, il y a une durée determinée des études, il n'y en a pas dans l'enseignement primaire. Voulez-vous faire faire à votre fils des études classiques: en le plaçant au collége, vous savez combien il doit y rester et ce qu'il y apprendra. Mettez-vous au contraire votre enfant dans une école: vous ne savez rien. Vous pouvez vous dire que vous l'y laisserez tant d'années ou jusqu'à tel âge; mais vous ne savez pas exactement ni ce qu'il y apprendra, ni combien d'annés vous devrez l'y laisser pour qu'il apprenne telle ou telle chose.". 
ensino primário. Nesse sentido, o número de divisões dentro da escola contribuía para agravar o problema.

Diz-se talvez que este aluno está na segunda ou terceira divisão, mas isso não lhe diz nada. O número de divisões está longe de ser o mesmo em todas escolas: a maior parte, é verdade, são em três, mas muitas são em quatro ou cinco; há até escolas onde se conta seis, sete, oito divisões ou até mais [...] (p. 13-14, tradução nossa). ${ }^{14}$

O número de divisões aumentava pela irregularidade de entrada de crianças durante todo o ano, problema também vivido pelos professores da Corte e de outras regiões do país: "Até hoje, nas escolas primárias, as crianças entram em qualquer época do ano, e essas chegadas sucessivas desorganizam a escola; é preciso criar para eles divisões particulares, de onde resulta um problema em todas as lições” (p. 15, tradução nossa). ${ }^{15}$

O fato de o professor ser o único responsável por todas as tarefas do ensino, igualmente, dificultava o trabalho escolar:

Na maior parte de nossas escolas, o professor está só para instruir os alunos de todas as idades e a todo grau de instrução, desde a criança que não sabe nada, que jamais viu um livro, que não conhece mesmo uma letra, a aquela que é preciso tudo ensinar, e às vezes mesmo aprender a falar, até o aluno que completou seus estudos e que está no ponto de abraçar uma carreira, até o adulto mesmo que já tem um estado, e que vem procurar com ele os meios de ser melhor sucedido na sua profissão. E não é uma só coisa, como nos colégios, que eles devem ensinar a seus alunos de idades tão diversas, é em todos os ramos da instrução primária que ele tem a missão de os instruir. Ele é só para tudo ensinar, a leitura e a escrita, o catecismo, a história santa, a gramática e a aritmética e a história e a geografia,

\footnotetext{
${ }^{14}$ No original: "On vous dira peut-être que cet élève est dans la deuxième ou la troisième division, mais cela ne vous apprend rien. Le nombre des divisions est loin d'être le même dans toutes les écoles: la plupart, il est vrai, en ont trois, mais beaucoup en ont quatre ou cinq; il y a même des écoles où l'on compte six, sept, huit divisions, et même plus [...]".

${ }^{15}$ No original: "Jusqu'à ce jour, dans les écoles primaires, les enfants entrent à toute époque de l'année, et par ces arrivées successives ils désorganisent l'école; il faut créer pour eux des divisions particulières, d'où résulte un trouble dan toutes les leçons”.
} 
o desenho linear e o canto, as ciências e a agricultura. Compreende bem as dificuldades de semelhante tarefa? (p. 19, tradução nossa). ${ }^{16}$

Se a utilização de um plano e programa de estudos resolveria muitos problemas, Rapet indaga o motivo da administração não estabelecer um uniforme para todas as escolas. A resposta seria simples, ele diz: "porque ela não quis submeter os professores primários a um grande incômodo, impondo-lhes um plano uniforme, que não corresponderia às habilidades diferentes de uns ou de outros, cada um pode fazê-lo hoje por si mesmo" (p. 32, tradução nossa) ${ }^{17} \mathrm{O}$ fato dos próprios professores fazerem os programas de suas escolas também se assemelhava às práticas dos professores brasileiros. Observa-se também o cuidado de Rapet em elaborar um discurso de respeito em relação aos mestres, de não lhes impor regras.

A segunda parte do livro destina-se a discutir a elaboração de um plano de estudos, o que era, "sem dúvida", uma tarefa árdua: "organizar um bom curso de ensino primário, estabelecer uma classificação judiciosa dos alunos, repartir todo o ensino entre as diferentes divisões, segundo o tempo que as crianças passem em geral na escola, e de maneira a manter todos sempre utilmente ocupados" (p. 35, tradução nossa). ${ }^{18}$

A classificação e a divisão dos alunos eram colocadas como questões primordiais na organização da escola e Rapet alegava que "Estabelecer três divisões

${ }^{16}$ No original: "Dans la plupart de nos écoles, l'instituteur est seul pour instruire des élèves de tout âge et à tout degré d'instruction, depuis l'enfant qui ne sait rien, qui n'a jamais vu un livre, qui ne connaît pas même une lettre, à qui il faut tout enseigner, et quelquefois même apprendre à parler, jusqu'à l'élève qui achève ses études et qui est sur le point d'embrasser une carrière, jusqu'à l'adulte même qui a déjà un état, et qui vient chercher auprès de lui les moyens de mieux réussir dans sa profession. Et ce n'est point une seule chose, comme dans les colléges, qu'ils doit enseigner à ces élèves d'âges si divers, c'est dans toutes les branches de l'instruction primaire qu'il a mission de les instruire. Il est seul pour tout leur enseigner, la lecture et l'écriture, le catéchisme, l'histoire sainte, la grammaire et l'arithmétique et l'histoire et la géographie, le dessin linéaire et le chant, les sciences et l'agriculture. Comprend-on bien les difficultés d'une pareille tâche?”

${ }^{17}$ No original: “[...] parce qu'elle n'a pas voulu soumettre les instituteurs à une trop grande gêne, en leur imposant un plan uniforme, qui ne correspondrait pas avec les aptitudes différentes des uns ou des autres, chacun peut le faire dès aujourd'hui pour soi-même."

${ }^{18}$ No original: "Organiser un bon cours de l'enseignement primaire, établir une classification judicieuse des élèves, répartir tout l'enseignement entre les différents divisions, selon le temps que les enfants passent en général dans l'école, et de manière à les tenir tous e toujours utilement occupés [...]". 
na sua classe é tudo o que é rigorosamente possível a um mestre só; para bem fazer, não se pode estabelecer nem mais nem menos" (p. 37, tradução nossa). ${ }^{19}$ Argumentava que, nas escolas com duas divisões, os alunos ficavam mais bem ocupados, mas muitos não aproveitariam as lições, pois se encontrariam em nível diferente dos demais. Naquelas com mais do que três divisões, os alunos ficavam mais bem classificados e fariam lições com mais aproveitamento, mas não se poderia fazer isso sem sacrifício dos demais. No caso de quatro divisões, cada classe teria 15 minutos com o mestre, ficando os outros três grupos 45 minutos sem assistência dele, o que poderia causar perturbações. No Plan d'études, Rapet usa o termo "divisões" para se referir à repartição dos alunos em três grupos, mas no Cours ele usa a expressão "curso" e cita como exemplo, "primeiro curso ou curso de primeiro ano". ${ }^{20}$ A organização dos alunos em três divisões era prescrita na França, segundo Jacquet-Francillon (1999), desde a implementação dos Estatutos das Escolas Primárias Comunais de 1834 e fazia parte do esquema do método simultâneo da pedagogia dos irmãos das escolas cristãs.

No entanto, Rapet argumenta que, mesmo nas escolas com três divisões, seria difícil manter os alunos ocupados e que existiam professores que se valiam da ajuda das crianças. Rapet então se preocupa em definir o que significa essa "ajuda”, já que não se tratava de um professor adjunto francês, nem do monitor do ensino mútuo. A ênfase na distinção em relação aos monitores pode ter a ver com a observação de Jacquet-Francillon (1999) acerca da “irritação" de Rapet com a sobrevivência do método mútuo em Reims. Assim, a ajuda não constituiria em

[...] um monitor como aqueles aos quais se dava esse nome nas escolas onde o ensino mútuo estava em uso. Os antigos monitores das escolas mútuas eram simples alunos escolhidos entre as próprias crianças, e tinham um pouco mais de instrução que aqueles que deviam ensinar. Era sobre eles que repousava o cuidado de ensino dado a todas as divisões, o diretor da escola não se ocupava mais que dar uma lição a seus monitores na manhã ou à tarde, antes ou após a classe. Voltamos ao erro que tinha

\footnotetext{
${ }^{19}$ No original: "Établir trois divisions dans sa classe est tout ce qui est rigoureusement possible à un maitre seul; pour bien faire, on peut en établir ni plus ni moins."

${ }^{20}$ Anne-Marie Chartier alerta que o curso poderia corresponder a mais de um ano de estudo, mas que tal prática não era explicitada oficialmente. Informação obtida em reunião de pesquisa em 9 de dezembro de 2013.
} 
feito supor durante um certo tempo que as crianças poderiam, a não ser por exceção, ser capazes de instruir outras crianças de mesma idade [...] (p. 45, tradução nossa). ${ }^{21}$

Rapet advoga uma ajuda intermediária entre os antigos monitores e os professores adjuntos propriamente ditos: "alguma coisa enfim de análoga aos aprendizes-mestres (pupils-teachers) cuja adoção trouxe uma tão feliz melhora ao ensino nas escolas de nossos vizinhos" (p. 46, tradução nossa). ${ }^{22}$ Interessante observar que a proposta da ajuda intermediária por alunos da escola muito se assemelhava à instituição do professor adjunto brasileiro, usada como meio de formar novos professores. Embora Rapet não informe a qual vizinho se referia, poderia ter sido o mesmo que inspirou o caso brasileiro, a Prússia, que o professor Costa e Cunha assinala como sendo a inimiga na qual a França também buscava inspirações.

Uma última observação que importa destacar para compreender a distribuição dos saberes consta no capítulo que discute as lições e exercícios a serem dados às crianças. Ao defender que as crianças que acabassem de chegar à escola fizessem quase tudo que os alunos mais velhos e que a escrita era, com a leitura, o que mais importava no ensino - porque eles não poderiam aprender uma lição sem saber ler, nem fazer nenhum dever sem saber escrever -, afirma que:

Durante muito tempo, acreditou-se que as crianças não podiam começar a escrever assim que soubessem ler: é mesmo, nós dissemos, sobre esta suposição que estava fundada no antigo costume de se pagar um preço diferente para os alunos que lessem somente e por aqueles que começassem a escrever. Mas este costume

${ }^{21}$ No original: "[...] n'est point un moniteur comme ceux auxquels on donnait ce nom dans les écoles où l'enseignement mutuel était en usage. Les anciens moniteurs des écoles mutuelles n'étaient que de simples élèves choisis parmi les enfants eux-mêmes, et ayant à peine un peu plus d'instruction que ceux qu'ils devaient instruire. C'était sur eux que reposait le soin de l'enseignement donné à toutes les divisions, le directeur de l'école ne s'occupait lui-même de cet enseignement que pour faire une leçon à ses moniteurs le matin ou le soir, avant ou après la classe. On est revenu de l'erreur qui avait fait supposer pendant un certain temp que les enfants pouvaient, autrement que par exception, être capables d'instruire d'autres enfants du même âge. [...]".

${ }^{22}$ No original: "[...] quelque chose enfin d'analogue aux apprentis-maîtres (pupils-teachers) dont l'addoption a apporté une si heureuse amélioration à l'enseignement dans les écoles de nos voisins". 
começou felizmente a desaparecer diante de um conhecimento mais exato dos princípios de ensino (p. 53, tradução nossa). ${ }^{23}$

A relação que Rapet faz entre a prática de ensinar a ler e a escrever separadamente e o pagamento diferenciado por tais habilidades mostra as conexões possivelmente existentes entre a pedagogia e a economia, aspecto que também se traduzia em outra prática mencionada por ele:

[...] em muitas escolas, quando o professor primário é casado, o que é quase sempre o caso, sua esposa preenchia com ele as funções de ajuda, com grande vantagem para a disciplina e o ensino. Este costume, excelente em relação às escolas que reúnem os dois sexos, pode ser muito utilmente introduzido naquelas onde só há meninos. As mulheres têm, para dirigir as jovens crianças, uma doçura e uma paciência que as fazem frequentemente mais bem sucedidas que os homens na instrução destes pequenos seres tão sensíveis e tão impressionáveis (p. 57, tradução nossa). ${ }^{24}$

Cabe destacar que a ideia de elaboração de um "programa-horário" não foi uma invenção de Jean-Jacques Rapet. Outros franceses já haviam se debruçado sobre o assunto e publicado obras, como o trabalho pedagógico dos "irmãos das escolas cristãs” e o sistema das escolas de ensino mútuo (Jacquet-Francillon, 1995). A intensa atividade de Rapet na elaboração e divulgação de um programa de ensino possivelmente tem a ver com a sua atividade de inspetor da instrução, que o levaria a observar, com maior proximidade com o cotidiano das escolas, a falta de uniformidade no ensino primário francês. O problema incomodava as

${ }^{23}$ No original: "Pendant longtemps, on a cru que les enfants ne pouvaient commencer à écrire que lorsqu'ils savaient lire: c'est même, avons-nous dit, sur cette supposition qu'était fondé l'ancien usage de faire payer un prix différent pour les élèves qui lisent seulement et pour ceux qui commencent à écrire. Mais cet usage a heureusement commencénè disparaître devant une connaissance plus exacte des principes de l'enseignement."

${ }^{24}$ No original: "[...] dans beaucoup d'écoles, lorsque l'instituteurs est marié, ce qui est presque toujours le cas, sa femme remplit auprès de lui les fonctions d'aide, au grand avantage de la discipline et de l'enseignement. Cet usage, excellent sous tant de rapport dans les écoles qui réunissent les deux sexes, peut être très-utilement introduit dans celle où il n'y a que des garçons. Les femmes ont, pour diriger les jeunes enfants, une douceur et une patience qui les font souvent mieux réussir que les hommes dans l'instruction de ces petits êtres si sensibles et si impressionnables." 
autoridades de uma forma geral e talvez compelisse o responsável mais imediato, no caso o inspetor geral, a buscar soluções.

\section{Entre a notoriedade e a insatisfação: o programa elaborado por Pardal}

O programa das escolas municipais que foi anexado em resposta à circular de 13 de julho de 1872 traz uma breve explicação que permite compreender alguns aspectos da forma como Pardal se apropriou de Rapet.

Faço consistir o curso, ou tempo de ensino, em 3 anos e cada um destes divido nos seus doze meses; sendo o $6 .^{\circ}$ e o $12 .^{\circ}$ para recapitulação, isto é, para adiantar aqueles alunos que se achem retardados por falta de frequência ou de aplicação, vindo por isso a haver 10 classes; distribuindo por elas o trabalho de cada ano, de modo que o professor não pode, a bem do sistema de ensino e fiscalização das escolas, ir além nem ficar aquém do que se acha determinado, para o aproveitamento mensal de seus alunos.

Parece-me que deste modo se obterá mais do que distribuído o trabalho do ano pelos dias letivos.

O curso de três anos, divididos por doze meses, sendo o $6 .^{\circ}$ e o $12 .^{\circ}$ para recapitulação, era o que também propunha Rapet. No caso francês, tais meses correspondiam aos períodos de férias escolares, enquanto no caso da Corte o recesso correspondia somente ao período de festividades do fim de ano. Esse fato era motivo de reclamação dos professores, que alegavam que a exiguidade das mesmas parecia "revelar um juízo muito desfavorável aos professores quanto à sua aplicação ao trabalho durante o ano letivo" (Resposta coletiva de professores eprofessoras à circular da Inspetoria Geral, 1873). Dessa forma, destacavam ser "incrível" que os professores da Província tivessem um mês de férias enquanto que "os pobres professores da Corte fechem suas escolas no dia 20 de dezembro para reabri-las a 7 de janeiro”.

Por manter as recapitulações, Pardal assinala que o programa de cada ano compreendia dez classes e não doze. Cabe lembrar que a tabela apresentada em 1855 sob o título "Chave do sistema de ensino" para a Escola Pública da freguesia de Santa Rita também compreendia dez classes, o que demonstra quanto a esse aspecto uma continuidade de parte de sua prática. 
No entanto, Pardal definia apenas os saberes de cada classe, ou seja, de cada mês, que era o tempo que cada uma correspondia, e não diariamente como no programa de Rapet. Ressalta que o professor não poderia ir além nem ficar aquém da programação para o "aproveitamento mensal de seus alunos”, mesmo procedimento assinalado pelo inspetor francês. Tal organização dos conteúdos, sem incorrer nas "miudezas" de cada dia, demonstra que o professor usou de sua autonomia e experiência para decidir até que ponto seguiria o "sistema de Rapet". O sistema, se seguido à risca, constituiria um trabalho "enfadonho" nas palavras de Pardal.

Este método, ou antes Cours d'études des écoles primaires públique sous la direction de Mr.J.J. Rapet, tem grandes inconvenientes: o $1^{\circ}$ é reduzir o professor a uma verdadeira máquina de trabalho enfadonho; $2^{\circ}$, é a desordem que traz a esse método os feriados imprevistos, sejam eles ocasionados por circunstâncias alheias ao professor, verbi-gralia um luto nacional, seja enfermidade repentina do professor ou seja, finalmente, pelas faltas dos alunos, e deste modo as lições que se deveriam dar nesses dias ficarão perdidas e não será isso pequeno prejuízo, atendendo-se à ligação e dependência dessas lições com as subsequentes.

Não obstante, alguns aspectos do programa de Pardal se assemelhavam à forma de distribuição das matérias sintetizadas em um quadro do livro de Rapet. O inspetor francês inclui na grade história e canto, disciplinas que não constavam no programa feito por Pardal (embora a "música vocal" fizesse parte das atividades da escola, como assinalou Ferreira Vianna em seu discurso de inauguração), mas no caso das demais, é possível observar similaridades e adaptações, como no ensino de geografia. A disciplina, em Rapet, estava destinada aos $2 .^{\circ}$ e $3 .^{\circ}$ anos e nas escolas municipais, apenas ao terceiro ano. Ao observarmos o conteúdo do programa, verificamos que a geografia do $3 .^{\circ}$ ano aparenta ser um resumo do conteúdo previsto para o $2 .^{\circ}$ e $3 .^{\circ}$ ano de Rapet. A geografia, segundo Rapet, havia se tornado obrigatória nas escolas primárias francesas apenas alguns anos antes por uma lei de 10 de abril 1867. 


\section{Figura 36 - Quadro de repartição das matérias do Cours d'études de Rapet}

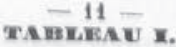

Répartition des matiècs de chaque branche d'instruetion entre les trots annes ou trois divisions du cours triennal.

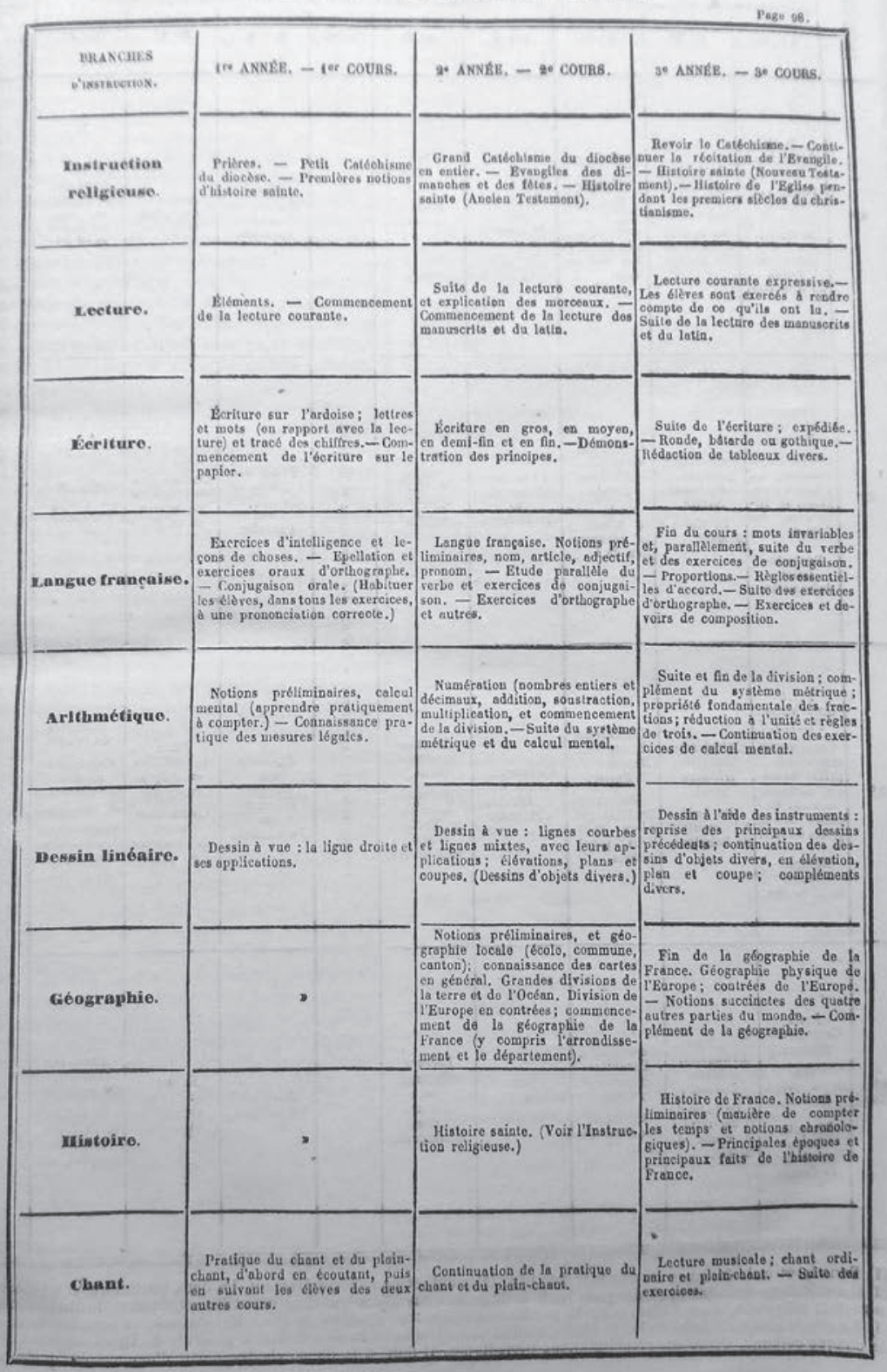

Fonte: BHVP. Foto da autora. 
Cabe destacar que, nas fontes pesquisadas há duas versões do programa de Pardal. Uma delas foi apresentada junto à circular de 13 de julho de 1872 e a outra foi enviada ao inspetor geral que a colocou em anexo ao seu relatório (anexos 1 e 2). A versão do programa anexada ao relatório do inspetor compreendia um conjunto de disciplinas que mudavam a cada ano. No primeiro ano, abarcava o ensino de leitura, escrita, aritmética, sistema métrico, desenho linear sem instrumentos e instrução religiosa. Nota-se que a leitura e a escrita eram ensinadas desde a primeira classe e possuíam quase a mesma carga horária, segundo a tabela que definia o tempo semanal de cada disciplina e sua distribuição de segunda a sábado.

Figura 37 - Quadro de horário do 1. ${ }^{\circ}$ ano enviado ao inspetor geral

\section{PIRIMEIRE ANNO}

\section{HORARIO PARA A ESCQLA DE S. SEBASTIÃO PARA MENINOS}

\begin{tabular}{|c|c|c|c|c|c|c|}
\hline TEMPO DE TRABALHO & $2^{a}$ FEIRA & $3^{a}$ FEIRA & $4^{3}$ FEIRA & $5^{a}$ FEIRA & $6^{a}$ FEIRA & SABBADO \\
\hline $\begin{array}{l}10 \text { horas } \\
10 \text { horas e } 15 \text { minutos } \\
11 \text { horas } e 15 \text { minutos } \\
12 \text { horas e } 15 \text { minutos } \\
1 \text { hora e } 15 \text { minutos } \\
2 \text { horas } 15 \text { minutos } \\
2 \text { horas e } 30 \text { minutos }\end{array}$ & $\mid \begin{array}{l}\text { Leitura .... } \\
\text { Arithmetica } \\
\text { Religiâo .... } \\
\text { Desenho ... }\end{array}$ & $\begin{array}{l}\text { Leitura..... } \\
\text { Arithmetica } \\
\text { Escripta_... } \\
\text { Metrologia. }\end{array}$ & $\begin{array}{c}\text { evista de as } \\
\text { Leitura.... } \\
\text { Religiäo... } \\
\text { Escripta... } \\
\text { Desenho... } \\
\text { Ponto e } \\
\text { Sahi }\end{array}$ & $\begin{array}{l}\text { Leio e oração. } \\
\text { Arithme.... } \\
\text { Escripta .... } \\
\text { Metrologia. } \\
\text { ração. } \\
\text { a }\end{array}$ & $\left|\begin{array}{l}\text { Leitura..... } \\
\text { Arithmetica } \\
\text { Escripta .... } \\
\text { Desenho... }\end{array}\right|$ & $\begin{array}{l}\text { Leitura. } \\
\text { Arithmetica } \\
\text { Escripta. } \\
\text { Religião. }\end{array}$ \\
\hline
\end{tabular}

Fonte: Relatório da IGIPSC, 1872.

Interessante notar na figura 37 que o ensino da religião não era previsto todos os dias, mas apenas em três deles (segundas, quartas e sábados), ou seja, possuía a mesma carga horária de desenho, embora a religião também se fizesse presente diariamente por meio da oração que precedia às aulas e provavelmente por livros escolares. A aritmética estava programada para ocorrer cinco vezes por semana e metrologia, duas. Cada tempo da disciplina correspondia a uma hora de atividades. Nesse sentido, pelo fato da escola funcionar de $10 \mathrm{~h}$ às $14 \mathrm{~h} 30$, cada dia era formado pelo ensino de quatro disciplinas diferentes, somando a isso o tempo para "revista de asseio e oração" no início e "ponto e oração" ao final, perfazendo teoricamente uma carga horária total de 24 horas semanais, 
divididas por seis horas de leitura, cinco de escrita, cinco de aritmética, três de desenho, três de instrução religiosa e duas de metrologia.

No caso da leitura, da primeira à quarta classe eram ensinados letras e dígrafos; na quinta, ditongos e sílabas; a partir da sétima, leitura silábica e leitura corrente com uso de manuais didáticos de Abílio Borges, Fábulas de Justiniano José da Rocha e Elementos de Civilidade. Segundo Teixeira (2008), entre os livros usados nas classes de leitura, havia os de história do Brasil, religião e ensino de moral, consistindo em um modo de ensinar os demais conhecimentos e de transmitir normas de comportamento e de moralidade.

$\mathrm{Na}$ parte da escrita, nas duas primeiras classes eram planejados exercícios de traçar linhas e círculos em ardósia; na terceira e quarta, as letras; na quinta e sexta, o alfabeto minúsculo e o maiúsculo; da sétima a nona, traçar as letras, agora em outro suporte, o papel, usando o "método caligráfico de Adler"; e, em seguida, traçar em formato "bastardo". Nas classes de aritmética as atividades começavam com contar e traçar números, contagem mental, tabuada mental da adição, depois da subtração e multiplicação. O sistema métrico, ao contrário das outras disciplinas, começava na sétima classe. Cabe observar que em todas as disciplinas, a $12^{\text {a }}$ classe era para recapitulação e também para exames.

O segundo ano era composto pelas mesmas disciplinas, com a diferença de que o sistema métrico começava já na primeira classe. No caso do terceiro ano, eram acrescidas as disciplinas de gramática, geografia e desenho linear com instrumentos. Os conteúdos e a ordem seguida no ensino de gramática se assemelhavam à organização da estrutura do compêndio que Pardal escreveu juntamente com José Ortiz, mas de maneira resumida e, aparentemente, com alguns cortes. $\mathrm{O}$ compêndio chamado Gramática Analitica e explicativa da língua portuguesa foi aprovado pelo Conselho Diretor da instrução para uso nas escolas públicas da Corte em dezembro de 1872 (Relatório da IGIPSC de 1873), após terem sido feitas alterações recomendadas pela "comissão revisora". A gramática substituiu a de Cyrillo Dilermando da Silveira que era usada nas escolas. Um relatório da Inspetoria de 1874 registra, a partir de uma listagem de fornecimento de livros, que, nesse período, um total de 382 exemplares da gramática de Pardal e Ortiz foram distribuídos nas escolas.

José Ortiz, segundo Sacramento Blake (1899), era nascido no Rio Grande do Sul, doutor em medicina pela Universidade de Paris e membro do Instituto Histórico da França. Optou por se dedicar à carreira do magistério, primeiro fundando um colégio em Itapemirim, no Espírito Santo, e depois no Liceu em Vitória, 
também Espírito Santo, sendo posteriormente professor em um liceu de Niterói, no Rio de Janeiro. Já havia publicado um livro sobre gramática portuguesa, em 1862, com um título extenso: "Novo sistema para estudar a gramática portuguesa por meio de memória, inteligência e análise, ajudando-se mutuamente”.

Após ser aprovada pelo Conselho Diretor, a gramática não ficou restrita ao município da Corte. O compêndio circulou nas propagandas de livrarias pelo país, como no caso dos jornais $A$ Constituição (CE), em 1876, O Leopoldinense Folh a comercial, agricola e noticiosa (MG), em 1882 e A Provincia de Matto-Grosso, em 1882. Também recebeu comentários críticos durante três semanas no periódico recifense $A$ Província - órgão do Partido Liberal (1874), o que pode ter uma conotação política, já que Pardal era associado ao grupo conservador. No Correio Oficial (Goyaz), de 3/05/1884, se observa que a obra fazia parte do programa da Escola Normal de Goiás que foi publicado no jornal. Já o Jornal do Aracaju (SE) publicou trechos de pareceres de Alambary Luz e Augusto Cony, com apresentação de um programa em que também consta a gramática (22 nov. 1873). E o Correio Paulistano (11 jun. 1878) ao dar notícias sobre o Colégio de Nossa senhora Mãe dos Homens e o Externato dos Aprendizes de São João de Ypanema, a pedido da Fábrica de Ferro Ypanema, afirma que em tais escolas era adotada a gramática. ${ }^{25}$ Em 1887 a Livraria Clássica, na Corte, vendia a 5a edição do livro (O Apóstolo, 26 jan. 1887). Essa livraria ainda fazia propaganda da obra em janeiro de 1889, após a morte de Pardal.

Segundo Sacramento Blake (1899), a obra teve seis edições. O exemplar que se encontra sob a guarda do LIVRES-USP (Banco de Dados de Livros Escolares Brasileiros da USP), datado de 1888, corresponde à última edição. Ela está dividida em quatro partes: etimologia, sintaxe, ortografia e prosódia. Cada informação abordada pelos autores foi numerada, somando um total de 506 itens.

Embora durante a pesquisa não tenha sido feita uma comparação com outras gramáticas escolares brasileiras, para observar semelhanças e diferenças no texto e na estrutura, chama a atenção o fato de ser bastante similar à estrutura e à sequência de tópicos da gramática escrita por Jean-Jacques Rapet, em coautoria com L.C. Michel, Cours Élémentaire de langue française: Principes de Grammaire Française (1853). Vale ressaltar que a primeira frase de ambos os livros, que visa conceituar o que é gramática, é bastante parecida: "Gramática

${ }^{25}$ Cabe destacar o envolvimento da Fábrica de Ferro Ypanema com a escolarização. Segundo Alcântara (2014), a Fábrica passou a produzir carteiras escolares para fornecer às escolas paulistas na década de 1870 . 
é a arte de falar e escrever corretamente"/ "La grammaire apprend à parler et à écrire correctement".

Essa frase foi severamente criticada por Albino de Meira, que escreveu alguns artigos sobre a gramática de Pardal e Ortiz no jornal recifense $A$ Província - órgão do Partido Liberal, nos meses de julho e agosto de 1874. Albino era professor de "língua nacional", colocado pelo governo em um "dos primeiros estabelecimentos de instrução pública” de Recife. O professor declara que ainda não havia adotado a gramática na escola, apesar dela estar ganhando "na classe estudiosa desta cidade rápido prestígio”. Albino acusa a gramática de possuir vários defeitos e, ao começar "pelo princípio", usa como exemplo justamente a primeira frase.

Gramática, dizem Ss. Ss. é a arte de falar e escrever corretamente. Essa definição é má, porque restringe sobremodo o objeto definido, reduzindo a gramática a sua prática, a uma grosseira materialidade, despojando-se de seu lado filosófico e científico. Falar e escrever corretamente, a prática desacompanhada da especulação e só auxiliada por uma atenção acurada pode conseguir, e há exemplos disto. Um analfabeto inteligente e observador pode falar não com tantos floreios (que pertencem à retórica), não com tanta ciência (que depende da instrução) mas com tanta correção como um letrado (A Provincia, 16 jul. 1874).

Essa primeira frase foi suficiente para render assunto para todo o primeiro artigo de Albino de Meira que ocupou três colunas do periódico. O professor também proferiu severas críticas ao método usado para abordar os temas e as definições apresentadas, comentando cada discordância minuciosamente, bem como fazendo condenações indiretas à inspetoria que aprovou a gramática. Albino apresenta, sobretudo, questóes relativas à forma de conceituar que considera imprecisa, superficial ou incompleta. No entanto, também cabe lembrar que era uma gramática destinada às escolas primárias. Talvez, o maior rebuscamento dos conceitos exigido por Albino não correspondesse às necessidades desse tipo de ensino.

O trabalho nas escolas municipais parece ter proporcionado a produção de outra obra de autoria de Pardal e do professor L. de Vasconcellos que, provavelmente, se tratava de Luiz Antonio Vieira de Barros e Vasconcellos, primeiro professor da Escola Municipal de São José, na época. O livro chamava-se Novo silabário e o jornal Gazeta de Notícias (23 dez. 1876), ao agradecer o exemplar 
enviado pelos autores, assinalava que havia sido organizado "em conformidade com o programa de estudos das escolas municipais da Corte”. O Novo silabário foi bem recebido pela crítica de alguns jornais, como $O$ Globo (27 jan. 1877) que ressaltava a vantagem "incontestável” para o ensino primário do livro escrito pelos "provectos” professores: “Afastando-se dos métodos até hoje seguidos, procuraram os inteligentes professores, facilitar o mais possível a leitura e para isso dividiram as letras do alfabeto em quatro grupos”. Não foi possível localizar um exemplar durante a pesquisa, o que seria imprescindível para contrastar a obra com o programa das escolas municipais e assim examinar a presença ou não das ideias de Rapet.

De modo geral, no interior da distribuição dos saberes no programa, podemos observar a adoção de livros dos professores Manoel Frazão, Matta Araujo, Ignacio Mesquita (que havia sido adjunto de Pardal quase duas décadas antes), Abílio Borges, Justiniano José da Rocha, Joaquim Manoel de Macedo, Philipe da Motta Azevedo, bem como o sistema caligráfico de Adler. Pardal ao elaborar o programa das escolas municipais adotou manuais de figuras conhecidas (como Macedo e Justiniano, seus colegas no Colégio de D. Pedro II), mas também tornou presentes as experiências pedagógicas das escolas públicas da Corte por meio dos livros produzidos por seus professores Frazão, Araújo e Mesquita.

O programa entregue ao inspetor geral, em virtude da solicitação feita para cumprir a fiscalização das escolas municipais, e o programa entregue em resposta à circular de 13 de julho 1872 e apresentado nas Conferências Pedagógicas diferem em alguns aspectos. O primeiro era uma cópia do adotado nas escolas municipais, enviado por razões burocráticas. Já o segundo consistia não no que exatamente os professores faziam, mas como Pardal achava que deveria ser nas escolas públicas da Corte. Com isso, foram retiradas do programa as disciplinas de desenho e geografia, o que talvez sinalizasse que o professor acreditava que, em se tratando de adotar um mesmo programa em toda a Corte, as escolas públicas poderiam não ter condições de ensinar tais saberes.

Segundo Pardal, o programa fundava-se "na exequibilidade do sistema simultâneo no aproveitamento de todo o tempo consagrado ao ensino, e na facilidade de uma boa fiscalização" (Resposta à circular, Relatório da IGIPSC referente ao ano de 1871, assinado em 1872). Entretanto, o programa parecia que não estava dando bons resultados: 
Pelo modo porque se tem até agora ministrado é além de lento, pouco satisfatório em seus resultados; o professor deve por sua parte ter uma tarefa a desempenhar, isto é, dar conta de um curso, em certo tempo.

Subdividindo os alunos em 3 anos e em horas diferentes, tenho por fim a boa disciplina e o maior aproveitamento dos mesmos alunos; aumento deste modo o trabalho do professor, mas a questão cifrar-se-á numa boa remuneração de nenhum modo comparável com a atual (Resposta à circular, Relatório da IGIPSC referente ao ano de 1871, assinado em 1872).

Apesar de usar ideias de Rapet, fato que ficou associado à sua imagem no meio docente, na imprensa e no governo, o professor demonstrou certa insatisfação com os resultados e reclamou de lentidão. A lentidão era prevista por Rapet, conforme consta nas explicações da introdução do Cours, e era considerada um benefício e não uma desvantagem, o que demonstra uma divergência na maneira de analisar o ritmo de ensino por parte dos dois personagens e que poderia apontar as urgências educacionais diferenciadas em cada país. Pardal também afirmou, imbuído de certa astúcia, que havia um aumento do trabalho do professor, o que não constituiria um problema em si, se o governo pagasse um salário correspondente ao esforço docente, alertando que tal remuneração não deveria ser "de nenhum modo comparável com a atual”.

Ao apresentar críticas ao sistema de Rapet, Pardal se insere na perspectiva de que as traduções, como traduções culturais, funcionam como atualização dos repertórios culturais, em que os modelos não são transferíveis, mas podem ser apropriados de forma crítica e criativa (Vidal, 2005). A partir da premissa que "descrê na mera transposição de uma prática pedagógica de um país ao outro", Vidal (2005, p. 132) ressalta a importância de um movimento de análise que consiste em:

[...] compreender a circulação de modelos culturais como fruto da passagem de pessoas e objetos entre mundos, recorrendo aos aportes da história conectada; e conceber as escolas e suas culturas como realidades sócio-históricas singulares, constituídas pela composição de saberes e prescrição de práticas e por sua apropriação criativa efetuadas pelos diferentes sujeitos da escolarização.

Dessa forma, vale destacar o "método particular" inventado pelo professor para a classe de leitura, do qual fazia propaganda e que poderia ser visto e examinado na Escola Municipal São Sebastião, ou seja, pela vitrine a ser admirada e avaliada. 
Não trato aqui dos meios práticos, ou do meu método em particular, para levar a efeito este plano, mormente as primeiras cinco classes de leitura, porque temo não me fazer compreender numa ligeira exposição, compatível como o espaço de que devo aqui dispor, porém ele acha-se em execução nas aulas primárias da escola municipal de S. Sebastião onde poderá ser visto e examinado.

Ao dar relevo ao método de sua invenção atrelado a um programa baseado em um trabalho francês, o professor lançava mão de duas estratégias: ao mesmo tempo em que demonstrava competência para apropriar-se de ideias estrangeiras, demonstrava que também tinha competência criar seus próprios “métodos". Os efeitos da divulgação do seu trabalho desenvolvido nas escolas municipais conferiram a ele autoridade no assunto e propiciaram o aparecimento de programas inspirados em Rapet, como um elaborado pela folha A Instrução Pública. Pretendendo ser divulgada como um trabalho coletivo, evidenciado pelo título do artigo "O nosso trabalho", a proposta era de autoria de Augusto Cony, publicada após uma introdução explicativa em torno do trabalho de Rapet (17 nov. 1872).

Nesse sentido, cabe assinalar a reflexão de Vidal (2005, p. 68) que, apoiada em Gruzinski, entende a "apropriação não como distorções do original, mas como reconstruções de significados que mesclam duas semânticas culturais, produzindo uma nova originalidade", o que pode situar o professor Pardal na condição de mediador cultural, conceito que

[...] positiva as sínteses ou apropriações efetuadas aos modelos pedagógicos e materiais escolares e coloca em destaque as singularidades sócio-históricas das comunidades nacionais, regionais ou mesmo institucionais, o que incide novamente sobre as propriedades da cultura escolar, concebida como original e produto/produtora da cultura social (Vidal, 2005, p.68).

O uso das ideias do inspetor francês por Augusto Cony e os elogios que faz ao trabalho de Pardal constituem uma forma de valorizar ou de chamar a atenção para sua própria prática, conforme pode ser percebido no parecer de Phillipe da Motta:

A dissertação do professor Cony revela conhecimentos teóricos e práticos, que o honram tanto mais, quanto há muito pouco tempo que se consagra no magistério publico. O seu estudo sobre a organização da escola, que ele aliás já tem 
ensaiado, parece satisfazer as necessidades do nosso ensino escolar elementar: o seu sistema já tem a favor o juízo esclarecido de notáveis pedagogistas franceses e depois de muitas de experiências foi definitivamente adotado nas escolas da França. Apropriando-a as escolas elementares primárias do município da corte, só resta que os professores nacionais digam a sua última palavra sobre ela. Já lhe serve de recomendação o fato de ter o decano do professorado público primário [Pardal] adotado um sistema análogo na organização das escolas municipais de cuja direção está encarregado (Relatório..., p. 7/1872-2A, A-B7-7).

No documento, o uso do sistema de Rapet por Cony é ratificado a partir da legitimação dada aos pareceres dos "pedagogistas franceses", das experiências nas escolas francesas e da sua adoção pelo professor Pardal, "decano do professorado público”. Três elementos são acionados: a expertise, a experiência e o exemplo local, que pareciam revestir o chamado "sistema de Rapet" de uma confiabilidade que permitiria lançar mão de sua adoção com garantias de sucesso, mesmo tendo Pardal feito ressalvas quanto a isso.

Contudo, assim como Pardal, Cony igualmente tinha reservas às ideias de Rapet. Segundo Phillipe da Motta, no debate oral, Cony criticou a organização das tabelas feitas por alguns professores - inclusive a do próprio Pardal - por achar impraticável a distribuição mais minuciosa do plano de estudos, "tendo-se apartado também nesse ponto do Sr. Rapet, não obstante ser a sua tabela baseada sobre o sistema daquele Sr." (Relatório de 1872-2A, p. 8, A-B7-8).

O programa de Pardal circulou na Corte e teve alguma circulação pelo país. A Instrucção Pública (04 maio 1873) relata, por exemplo, que o programa foi publicado na Revista Pedagógica de Pernambuco. O nome de Rapet também se tornou familiar, como podemos ver na Revista $A$ Escola, ao tratar da Exposição Universal de Paris de 1878, cujo segundo grupo era intitulado "Educação e ensino, material e processo das artes liberais", sendo a sexta classe exclusiva para o ensino primário. A revista relata que júri da respectiva "classe" era composto por diversos profissionais, professores primários de Paris e por Rapet "nome já conhecido entre nós" (1877, p. 277).

Alguns aspectos gerais em torno da adoção de programas remetem às condições de aparecimento e aos seus efeitos. Na época em que Rapet trabalhou na elaboração de seu Cours d'études, houve um processo de grande mudança na França no que diz respeito ao material escolar, que permitiu a viabilidade do Cours: a adoção de cadernos para todos os alunos, o que não existia antes de 1855. Outra questão 
é o fato do programa que se pretendia implementar com tempo pré-determinado de execução começar a produzir uma condição até então inexistente na época, o "fracasso escolar". O programa tal como pensado iria obrigar os alunos da mesma classe a executarem a mesma tarefa ao mesmo tempo, diferentemente do que ocorria antes. Até então, o aluno que não tinha prazo para terminar os estudos (a não ser o da idade) poderia demorar vários anos para concluir o ensino primário e ficar pronto para prestar os exames necessários para obtenção de certificação, sem ser estigmatizado. Na medida em que se estabelece um tempo limite para conclusão da aprendizagem, por exemplo, de três anos, o aluno que levasse seis anos para concluir passaria a ser classificado na condição de fracasso escolar. ${ }^{26}$ Assim, como discorrem Chapoulie e Briand (2001), decisões de amplitude limitada como uma nova regulamentação de concurso ou de definição de idades podem gerar, a longo prazo, modificações consideráveis nas situações escolares.

Embora a discussão e os problemas acerca da adoção de programas não tenham se encerrado na Corte com os debates na década de 1870 , nem que a questão do "fracasso escolar" tivesse emergido como tal no período estudado, torna-se importante atentar para a geração de efeitos considerados negativos por medidas tomadas com intuito de melhorar o ensino.

\section{“Textos sem fronteiras": o acesso às obras de Rapet}

Como os professores públicos primários acessavam as obras de Rapet? Não foi possível localizar dados que registrassem explicitamente a forma como se deu o acesso. No entanto, elementos e vestígios presentes nas fontes indicam alguns caminhos possíveis. Também cabe considerar que não existiam traduções das obras de Rapet, o que, portanto, exigiria o conhecimento da língua francesa por parte dos professores. Nesse sentido, Roger Chartier, em seminário intitulado Textes sans frontières, ${ }^{27}$ ao tratar da geografia da circulação das obras e da existência de um mundo do leitor e um mundo do texto, assinala o papel importante que as tipografias assumiam em tais mundos na difusão dos textos, bem como determinadas atividades de diferentes sujeitos ligados aos impressos de diversas formas. Em que pesem as divisões políticas e geográficas dos territórios, a circulação de textos não tinha fronteiras.

\footnotetext{
${ }^{26}$ Reflexóes sugeridas em reunião de pesquisa pela professora Anne-Marie Chartier em 9 de dezembro de 2013.

${ }^{27}$ Curso proferido no Collège de France entre outubro e dezembro de 2013.
} 
Na segunda metade do século XIX, ocorre um intenso movimento de introdução de inovações pedagógicas, alargada pelas notícias trazidas das Exposições Universais e por outros mecanismos, como alguns elencados por Hilsdorf: publicação dos relatórios de Célestin Hippeau; compra de literatura pedagógica internacional "por intermédio de catálogos de obras que os livreiros nacionais e do exterior remetiam pelos correios para todas as províncias do Império”; "dos novos materiais pedagógicos, que os agentes comerciais das grandes firmas importadoras exibiam nos seus catálogos de mercadorias" (Hilsdorf, 2003, p. 52), entre outros.

Tal movimento fazia parte de um processo de invenção da modernidade educativa, como assevera Vidal (2009), em que a circulação de sujeitos, modelos e objetos pedagógicos se associava também a um crescente mercado alimentado pela obrigatoriedade escolar, bem como às traduções culturais e apropriações "dos sujeitos diante dos repertórios colocados à sua disposição" (p. 37) e que remetem aos "circuitos culturais".

No caso desta investigação, entre algumas possibilidades, duas podem ser destacadas por se fazerem presentes com mais intensidade no material pesquisado: imprensa e bibliotecas. Segundo Caparelli, os franceses "animaram o panorama da imprensa brasileira do século XIX” e de certa maneira constituíram os mais importantes impressores e livreiros do Brasil na época. Ressalta que os “intelectuais brasileiros" não foram os únicos mediadores culturais do mundo da imprensa oitocentista: "Livreiros, tipógrafos e impressores, brasileiros e franceses, também foram essenciais para a configuração da imprensa brasileira” (2012, p. 34). Elencando ainda os colaboradores da imprensa, o autor demarca, dessa forma, que a "própria experiência de imprensa é uma experiência coletiva".

Vasconcelos (2012), em estudo sobre a Revue des deux mondes, criada em 1829 para "fazer uma ponte entre o velho e o novo continentes", também afirma que esta e outras revistas francesas contribuíram "de forma decisiva para a difusão de diferentes autores e para a disseminação de juízos críticos sobre suas realizações” (p. 107).

Tais observações constituem elementos importantes para refletir sobre o ambiente jornalístico carioca, no qual os professores também estavam imersos e por meio do qual poderiam acessar os mais variados tipos de autores e textos. No entanto, tal acesso poderia não se dar de maneira contínua, criando situações em que os professores deixassem de acompanhar certas leituras em alguns momentos e retomassem de outro ponto. A interrupção e dificuldade de acesso às informações completas poderiam explicar a confusão dos professores em torno 
das datas de produção da obra de Rapet em discussão no período. Os professores atestam, como se repetissem a informação do primeiro que a afirmou, que Rapet levou quase oito anos para concluir o Cours d'études, de 1863 a 1871. O fato coloca ao menos duas questões. A primeira é que desconheciam que em 1863 a obra já existia e que foi o ano em que o Ministro da Instrução Pública francesa a incluiu na lista de obras autorizadas para biblioteca escolar. A segunda questão é que isso nos fornece a pista de que, talvez, o acesso à obra tenha se dado a partir de 1871, sendo provável que o exemplar consultado pelos professores fosse o da edição apresentada na figura 37.

Cabe assinalar que $A$ Instruçãa Pública menciona jornais pedagógicos franceses, o que demonstra que possuíam algum tipo de contato com os mesmos, como o Bulletin Administratif du Ministère de l'Instruction Publique, L'Instruction Publique e o Journal des Instituteurs. Este último contava com intensa participação de Jean-Jacques Rapet e foi onde também publicou seu Cours d'études. De acordo com Villela, na segunda metade do século XIX:

Havia igualmente um grande interesse pela importação de periódicos estrangeiros, muitos deles abordando assuntos educacionais como A "Revue de Deux Mondes", "L'Ilustraction”, “Journal des Savants", a "Quartely Review” e jornais pedagógicos como o "Journal des Instituteurs" e "L’Echo des Instituteurs" (2002c, p. 3).

Um dos possíveis espaços frequentados por professores e que poderiam constituir um importante modo de formação e circulação de ideias relacionadas ao ofício de ensinar aparece sinalizado nos estudos de Tânia Bessone. A autora afirma que o maior número de leitores do Brasil estava concentrado na capital do Império e, do mesmo modo, "o maior número de livrarias, muitas bibliotecas públicas, colégios, alguns cursos superiores, publicações variadas como jornais e almanaques, um razoável número de bibliotecas particulares" (2005, p. 1). Em um trabalho sobre a formação de leitores e a influência exercida pela criação de bibliotecas e núcleos de estudo vinculados a associações luso-brasileiras, Bessone atesta que os cariocas

[...] tinham algumas opções de adquirir livros nas livrarias e sebos que representavam uma especialização dos armazéns de secos e molhados ou por meio de leilóes divulgados pelos jornais. $\mathrm{O}$ número de bibliotecas públicas foi se ampliando tornando-as mais acessíveis para aqueles que sabiam e precisavam ler mas não dispunham de 
recursos suficientes para adquirir obras e formar pequenos acervos ou bibliotecas particulares (p. 5).

Em uma pesquisa sobre o Real Gabinete Português de Leitura, a autora apresentou uma lista de livros do catálogo do ano de 1858, em que podemos observar a existência de 105 obras sobre educação. Um acervo considerável para época e que levanta a questão de quem o acessava e como se dava a consulta. Bessone afirma que tanto o gabinete quanto outras bibliotecas "divulgavam no Jornal do Commercio estatísticas acerca do número de leitores, volumes, idiomas das obras consultadas e assuntos da predileção dos usuários” (2001, p. 5). Este é um dado interessante que pode nos fornecer pistas sobre a presença ou não de professores, ou pelo menos de pessoas interessadas na temática da educação. Bessone também chama atenção para o fato de que "como espaço de sociabilidade, o Gabinete teria sido responsável pela intensificação de laços afetivos, políticos e profissionais entre seus frequentadores" (2001, p. 3).

No catálogo de livros de 1868 do Real Gabinete consta o livro de Rapet intitulado Manuel Populaire de Morale et d'économie politique à l'usage des classes ouvrières. Apesar do título não fazer menção a questões escolares, ele foi usado para discussão sobre as caixas econômicas escolares em artigo publicado no Diário do Rio de Janeiro de 13 de janeiro de 1878. Também se encontrava no catálogo um livro de Michel Charbonneau, Cours théorique et pratique de pédagogie, cuja introdução foi escrita por Rapet. Charbonneau havia sido discípulo de Rapet na Escola Normal de Périgueux e foi mencionado pelos professores nas Conferências de 1873.

As bibliotecas constituíam, portanto, espaços férteis com acervos compostos por livros e periódicos estrangeiros. Algumas estavam inseridas no interior de diversos tipos de instituições, como associações, institutos, colégios e faculdades. Os professores faziam parte de várias delas, como a Sociedade Auxiliadora da Indústria Nacional, em cujas atas consta o interesse em adquirir obras pedagógicas. O Colégio de Pedro II era outro lugar com biblioteca, assim como a própria Inspetoria Geral de Instrução. No entanto, é preciso não esquecer igualmente a iniciativa entre os próprios professores públicos primários de montar bibliotecas, conforme assinalado anteriormente. 
A partir das reflexões de Detienne (2004), podemos observar que o "território em comum” entre Pardal e Rapet - em pequena escala - e entre parte da instrução pública brasileira e a francesa, em maior escala, girava em torno do modo de organizar um programa de ensino. Tendo os saberes previamente estabelecidos pelas legislações em vigor, tratava-se da maneira de distribuir e escalonar os saberes pelo tempo disponível do horário escolar.

O "curso" concebido por Rapet procurava dar solução para uma série de problemas existentes nas escolas públicas francesas com similaridades com alguns problemas da realidade brasileira. Entre uma e outra realidade, Pardal, a partir de sua experiência, opera certa mediação, ainda que por meio da exposição de um trabalho de "apropriação criativa", favorecendo o acesso e o uso das ideias de Rapet por outros professores da Corte, divulgação que não se restringiu ao Rio de Janeiro.

A divulgação de ideias francesas - e mais especificamente de Rapet - nos jornais possibilitou o estabelecimento de conexões dos professores brasileiros com um certo tipo de discussão da França. Mas também observamos a possibilidade dos franceses acompanharem algumas questões brasileiras. Tais fatos demonstram que a circulação internacional de ideias, como afirma Vidal (2006), envolvia vários centros difusores, sujeitos, trabalhos e instituições de uma geografia expandida. 